\title{
Chemical Looping Combustion of Methane: A Technology Development View
}

\author{
Rutuja Bhoje, ${ }^{1}$ Ganesh R. Kale, ${ }^{1}$ Nitin Labhsetwar, ${ }^{2}$ and Sonali Borkhade ${ }^{1}$ \\ ${ }^{1}$ CSIR-National Chemical Laboratory (CSIR-NCL), Pune 411008, India \\ ${ }^{2}$ CSIR-National Environmental Engineering Research Institute (CSIR-NEERI), Nagpur 440020, India \\ Correspondence should be addressed to Ganesh R. Kale; gr.kale@ncl.res.in
}

Received 22 February 2013; Accepted 5 August 2013

Academic Editor: Qingjie Guo

Copyright (c) 2013 Rutuja Bhoje et al. This is an open access article distributed under the Creative Commons Attribution License, which permits unrestricted use, distribution, and reproduction in any medium, provided the original work is properly cited.

\begin{abstract}
Methane is a reliable and an abundantly available energy source occurring in nature as natural gas, biogas, landfill gas, and so forth. Clean energy generation using methane can be accomplished by using chemical looping combustion. This theoretical study for chemical looping combustion of methane was done to consider some key technology development points to help the process engineer choose the right oxygen carrier and process conditions. Combined maximum product $\left(\mathrm{H}_{2} \mathrm{O}+\mathrm{CO}_{2}\right)$ generation, weight of the oxygen carrier, net enthalpy of CLC process, byproduct formation, $\mathrm{CO}_{2}$ emission from the air reactor, and net energy obtainable per unit weight (gram) of oxygen carrier in chemical looping combustion can be important parameters for CLC operation. Carbon formed in the fuel reactor was oxidised in the air reactor and that increased the net energy obtainable from the CLC process but resulted in $\mathrm{CO}_{2}$ emission from the air reactor. Use of $\mathrm{CaSO}_{4}$ as oxygen carrier generated maximum energy $\left(-5.3657 \mathrm{~kJ}, 800^{\circ} \mathrm{C}\right)$ per gram of oxygen carrier used in the CLC process and was found to be the best oxygen carrier for methane CLC. Such a model study can be useful to identify the potential oxygen carriers for different fuel CLC systems.
\end{abstract}

\section{Introduction}

Energy demand and thus energy generation are ever increasing in many parts of the world. Carbon-based fossil fuels are the main source of energy for combustion reactions. However, the major product of energy generation using fossil fuels by combustion is $\mathrm{CO}_{2}$, and growing $\mathrm{CO}_{2}$ pollution has become a matter of serious concern amongst developed as well as developing countries. $\mathrm{CO}_{2}$ is mainly emitted from energy sector that uses coal, oil, and natural gas for combustion to generate energy for different purposes using air as an oxygen source. Although $\mathrm{CO}_{2}$ capture and sequestration is being projected as a potential option to control GHG emissions, $\mathrm{CO}_{2}$ capture technologies in-vogue are beset with several limitations including cost and energy penalty $[1,2]$. Hence, these flue gases are directly vented to the atmosphere without $\mathrm{CO}_{2}$ separation and became responsible for environmental impacts of energy generation from fossil fuels, for example, global warming and climate change phenomena [3-5]. In 2010, $\mathrm{CO}_{2}$ emissions have already increased to $389.0 \mathrm{ppm}$ and the burning of fossil fuels is one of the main causes for the same as reported by World Meteorological Organization [6]. This has promoted the development of clean energy technologies as a major research area worldwide. Chemical looping combustion (CLC) is an emerging clean energy technology to generate energy using abundantly available fuels and also provides sequestration ready $\mathrm{CO}_{2}$ stream $[7,8]$. CLC uses a solid oxygen carrier $(\mathrm{OC})$ to oxidize the carbon and hydrogen in the fossil fuel to $\mathrm{CO}_{2}$ and $\mathrm{H}_{2} \mathrm{O}$ in an endothermic fuel reactor. The reduced OC is regenerated by air oxidation in the exothermic air reactor $[9,10]$ in the next step. Both reactors are interconnected and operate simultaneously. The energy released in the CLC system is considered to be of similar magnitude as direct combustion but with a crucial advantage of having separate $\mathrm{CO}_{2}$ stream $[11,12]$. The pure $\mathrm{CO}_{2}$ steam can be captured/sequestered easily, thereby reducing $\mathrm{CO}_{2}$ emissions to atmosphere [13].

Development of chemical looping combustion technology requires the relatively cheap and long term availability 
of fuel and oxygen carrier. Fossil fuel such as methane is abundantly available as natural gas in many countries [1421]. It is also available as biogas [22-25], landfill gas [2631], gas hydrates [32-35], and coal bed methane [36] and can be generated from other organic wastes [37-40], and it is a major source of energy by combustion worldwide [41]. The selection of a suitable oxygen carrier (OC) for methane CLC is one the most important aspects for successful technology development study. Apart from the low-cost and abundant availability criteria, the OC must have suitable reactivity with the fuel, easy reducibility, and regenerability under CLC conditions in addition to some other essential properties such as high melting point, attrition resistance, mechanical stability, negligible loses during operation, negligible toxicity, and environmental impacts. The suitability of the oxygen carrier for a fuel can be determined by trial experiments and also by theoretical studies. Some theoretical (thermodynamic) studies of chemical looping combustion have already been reported [42-44], while experimental research studies of chemical looping combustion using methane as fuel with different oxygen carriers have also been published. Mattisson et al. [45] have proposed kinetic data of a promising oxygen carrier consisting $\mathrm{NiO} / \mathrm{NiAl}_{2} \mathrm{O}_{4}$ from experiments in a small fluidized-bed batch reactor using methane as fuel. Corbella and Palacios [46] have experimentally tested titania-supported iron oxides with different iron loadings in a fixed-bed quartz reactor in multicycle tests in a fixedbed reactor for methane CLC. Johansson et al. [47] have experimentally studied manganese oxides on pure zirconia and zirconia stabilized by $\mathrm{CaO}, \mathrm{MgO}$, or $\mathrm{CeO}_{2}$ as oxygen carrier in a laboratory fluidized-bed reactor of quartz for CLC of methane. Rydén et al. [48] have experimentally investigated red iron oxide, brown iron oxide and iron oxide scales and NiO-based particles as oxygen carrier in a batch fluidized-bed reactor in CLC of methane. Forero et al. [49] have experimentally evaluated $\mathrm{Cu}$-based oxygen carrier in a continuous CLC plant operating with methane and also $\mathrm{H}_{2} \mathrm{~S}$ as fuel. Kuusik et al. [50] have studied the NiO-based oxygen carriers under oxidising and reducing conditions using ceramic fluidized-bed furnace at high temperatures in CLC of methane. Zafar et al. [51] have proposed reduction and oxidation kinetics of $\mathrm{Mn}_{3} \mathrm{O}_{4} / \mathrm{Mg}=\mathrm{ZrO}_{2}$ oxygen carrier particles in CLC of methane. Abad et al. [52] have studied CLC of methane with $\mathrm{CuO}$ impregnated on alumina and developed mathematical model for fluidized bed. Song et al. [53] have studied the chemical-looping combustion of methane with calcium sulfate as a novel oxygen carrier in a laboratory scale fixed-bed reactor.

These studies are helpful to understand the kinetics/reactivity in CLC of methane with different oxygen carriers. However, a theoretical study about CLC with a focus on some important parameters for technology development view is not yet published in the literature to the best of our knowledge. The present study therefore aimed to determine theoretical aspects that can help the technology development criteria for CLC of methane. This study considers the key technology development issues in CLC of methane to evaluate suitability of the oxygen carriers based on other important process parameters such as net desired product generation, net energy obtainable from the system, byproduct generation, fuel conversion, relative weight of the oxygen carriers, effect of pressure and amount of oxygen carrier, and air requirement in oxidation reactor, which are vital parameters to be considered for CLC process design and its practical exploitation.

Technology development requires the use of low-cost, easily available oxygen carrier that can be tested rigorously and repeatedly during experimentation and must have low weight to enable fluidization and transport at low energy consumption in CLC. A detailed theoretical study is essential before experimentation to reduce the efforts of trial experimentation, which are often quite tedious and with several variables significantly affecting the results. Hence, this theoretical study was limited to low-cost, easily available oxygen carriers, preferably simple inorganic compounds consisting of common oxides and sulphates to enable swift experimentation and put technoeconomic potential and commercialization aspects on fast track. Selection of low-cost and easily available oxygen carriers has been discussed in detail in some studies $[54,55]$. Based on a similar analysis, the following oxygen carriers were selected for the present study:

$$
\mathrm{NiO}, \mathrm{Fe}_{2} \mathrm{O}_{3}, \mathrm{Mn}_{2} \mathrm{O}_{3}, \mathrm{CaSO}_{4}, \mathrm{Na}_{2} \mathrm{SO}_{4}, \mathrm{CoO}, \mathrm{CuO}
$$

The stoichiometric chemical reactions of the oxygen carrier reduction by methane in the fuel reactor as well as the oxygen carrier regeneration by oxygen (air) in the oxidation reactor are presented in Table 1.

\section{Methodology}

The main reactions for CLC of methane are

$$
\text { fuel reactor: } \begin{aligned}
\mathrm{CH}_{4}(\mathrm{~g}) & +4 \mathrm{MeO} \\
& =4 \mathrm{Me}+2 \mathrm{H}_{2} \mathrm{O}(\mathrm{g})+\mathrm{CO}_{2}(\mathrm{~g})
\end{aligned}
$$

air reactor: $\mathrm{Me}+0.5 \mathrm{O}_{2}=\mathrm{MeO}$

where Me is a divalent metal.

Some side reactions leading to byproducts may also occur in the fuel reactor and are listed below:

$\mathrm{CO}$ and $\mathrm{H}_{2}$ formation: $\mathrm{CH}_{4}+\mathrm{MeO}=\mathrm{CO}+2 \mathrm{H}_{2}+\mathrm{Me}$

carbon formation:

$$
\begin{aligned}
\mathrm{CO}+\mathrm{H}_{2} & =\mathrm{H}_{2} \mathrm{O}+\mathrm{C} \\
\mathrm{CH}_{4} & =\mathrm{C}+2 \mathrm{H}_{2} \\
2 \mathrm{CO} & =\mathrm{CO}_{2}+\mathrm{C}
\end{aligned}
$$

The fuel reactor product stream has a complex composition. Hence, thermodynamic equilibrium calculations were used to obtain the composition of the product stream of the fuel reactor. These calculations generally use Gibbs free energy minimization algorithms [56-59], simultaneous solution of nonlinear reaction equations using MATLAB programs, or equilibrium reactor modules of commercial software like Design II, HYSYS, or Aspen Plus. The simultaneous solution of nonlinear reaction equations based on 
TABLE 1: Stoichiometric chemical reactions for CLC of methane.

\begin{tabular}{|c|c|c|}
\hline Oxygen carrier & Reaction in fuel reactor & Reaction in air reactor \\
\hline $\mathrm{NiO}$ & $4 \mathrm{NiO}+\mathrm{CH}_{4}(\mathrm{~g})=4 \mathrm{Ni}+2 \mathrm{H}_{2} \mathrm{O}(\mathrm{g})+\mathrm{CO}_{2}(\mathrm{~g})$ & $\mathrm{Ni}+0.5 \mathrm{O}_{2}(\mathrm{~g})=\mathrm{NiO}$ \\
\hline $\mathrm{CuO}$ & $4 \mathrm{CuO}+\mathrm{CH}_{4}(\mathrm{~g})=4 \mathrm{Cu}+2 \mathrm{H}_{2} \mathrm{O}(\mathrm{g})+\mathrm{CO}_{2}(\mathrm{~g})$ & $\mathrm{Cu}+0.5 \mathrm{O}_{2}(\mathrm{~g})=\mathrm{CuO}$ \\
\hline $\mathrm{CoO}$ & $4 \mathrm{CoO}+\mathrm{CH}_{4}(\mathrm{~g})=4 \mathrm{Co}+2 \mathrm{H}_{2} \mathrm{O}(\mathrm{g})+\mathrm{CO}_{2}(\mathrm{~g})$ & $\mathrm{Co}+0.5 \mathrm{O}_{2}(\mathrm{~g})=\mathrm{CoO}$ \\
\hline $\mathrm{CaSO}_{4}$ & $\mathrm{CaSO}_{4}+\mathrm{CH}_{4}(\mathrm{~g})=\mathrm{CaS}+2 \mathrm{H}_{2} \mathrm{O}(\mathrm{g})+\mathrm{CO}_{2}(\mathrm{~g})$ & $\mathrm{CaS}+2 \mathrm{O}_{2}=\mathrm{CaSO}_{4}$ \\
\hline $\mathrm{Na}_{2} \mathrm{SO}_{4}$ & $\mathrm{Na}_{2} \mathrm{SO}_{4}+\mathrm{CH}_{4}(\mathrm{~g})=\mathrm{Na}_{2} \mathrm{~S}+2 \mathrm{H}_{2} \mathrm{O}(\mathrm{g})+\mathrm{CO}_{2}(\mathrm{~g})$ & $\mathrm{Na}_{2} \mathrm{~S}+2 \mathrm{O}_{2}=\mathrm{Na}_{2} \mathrm{SO}_{4}$ \\
\hline $\mathrm{Fe}_{2} \mathrm{O}_{3}$ & $1.33 \mathrm{Fe}_{2} \mathrm{O}_{3}+\mathrm{CH}_{4}(\mathrm{~g})=2.66 \mathrm{Fe}+2 \mathrm{H}_{2} \mathrm{O}(\mathrm{g})+\mathrm{CO}_{2}(\mathrm{~g})$ & $\begin{array}{c}\mathrm{Fe}+0.75 \mathrm{O}_{2}(\mathrm{~g})=0.5 \mathrm{Fe}_{2} \mathrm{O}_{3} \\
\mathrm{Fe}_{3} \mathrm{O}_{4}+0.25 \mathrm{O}_{2}(\mathrm{~g})=1.5 \mathrm{Fe}_{2} \mathrm{O}_{3} \\
\mathrm{FeO}+0.25 \mathrm{O}_{2}(\mathrm{~g})=0.5 \mathrm{Fe}_{2} \mathrm{O}_{3}\end{array}$ \\
\hline $\mathrm{Mn}_{2} \mathrm{O}_{3}$ & $1.33 \mathrm{Mn}_{2} \mathrm{O}_{3}+\mathrm{CH}_{4}(\mathrm{~g})=2.66 \mathrm{Mn}+2 \mathrm{H}_{2} \mathrm{O}(\mathrm{g})+\mathrm{CO}_{2}(\mathrm{~g})$ & $\begin{array}{l}\mathrm{Mn}+0.75 \mathrm{O}_{2}(\mathrm{~g})=0.5 \mathrm{Mn}_{2} \mathrm{O}_{3} \\
\mathrm{MnO}+0.25 \mathrm{O}_{2}(\mathrm{~g})=0.5 \mathrm{Mn}_{2} \mathrm{O}_{3}\end{array}$ \\
\hline
\end{tabular}

equilibrium constants might sometimes become stiff and nonsolvable. An alternate procedure to calculate equilibrium that takes account of chemical species only (not chemical reactions) based on minimization of the total Gibbs energy $G_{t}$ is shown by the expression:

$$
\left(\partial G_{t}\right)_{T, P}=0 .
$$

It shows that all irreversible processes occurring at some constant $T$ (temperature) and $P$ (pressure) proceed in a direction to the equilibrium state that has the lowest total Gibbs energy attainable at the given $T$ and $P$. The method is based on the set of species and is better than that of independent reactions among the species, as the number and nature of chemical reaction equations are not always known perfectly in a new system. HSC Chemistry version 5.1 [60] has been used for this thermodynamic equilibrium study. It uses the Gibbs free minimization algorithm to find the equilibrium compositions using species and not chemical reaction equations. This software is popular and user friendly [61]. Detailed description about calculation of thermodynamic equilibrium using HSC Chemistry is already discussed [62-65]. The species such as $\mathrm{CH}_{4}(\mathrm{~g}), \mathrm{CO}_{2}(\mathrm{~g})$, $\mathrm{H}_{2} \mathrm{O}(\mathrm{g}), \mathrm{CO}(\mathrm{g}), \mathrm{H}_{2}(\mathrm{~g})$, and $\mathrm{C}$ (solid) are considered in this study. Oxygen carriers such as (solid) $\mathrm{NiO}$ [66-68], $\mathrm{CuO}$ $[69,70], \mathrm{CoO}[71,72], \mathrm{CaSO}_{4}[73-76]$, and $\mathrm{Fe}_{2} \mathrm{O}_{3}[77,78]$ have been successfully used in chemical-looping studies. Hence, only these oxygen carriers (including hydroxides and carbonates, all solids) along with $\mathrm{Na}_{2} \mathrm{SO}_{4}$ and $\mathrm{Mn}_{2} \mathrm{O}_{3}$ were considered in this study. Table 2 shows the species (with reduced oxygen carrier species) used for each oxygen carrier.

The input species are methane and oxygen carrier at the particular temperature-pressure condition. No other product-byproduct formations are considered in this study. One mole of methane feed is considered in all the calculations and stoichiometric quantities of oxygen carrier have been used (defined by (2) and (3)). The equilibrium study is limited only to the gas-solid reaction in the fuel reactor. It is assumed that the air reactor conversions are complete due to extremely fast oxidation reactions. The material and energy balance calculations were performed using the inbuilt databases in the HSC Chemistry software package. It is also assumed that the CLC fuel and air reactor operate at the same temperature. The reaction products are assumed to be in thermodynamic equilibrium in the exit of the CLC fuel reactor. The operating temperature range for this study was 600 to $1200^{\circ} \mathrm{C}$ at 1 bar pressure especially considering methane as fuel. The equilibrium composition data generated by the equilibrium composition module was further used to generate the enthalpy data using the reaction equations module of HSC Chemistry package, for example, input of $\left(\mathrm{CH}_{4}(\mathrm{~g})+4 \mathrm{NiO}\right)$ to the equilibrium composition module produced, $\left(0.1554 \mathrm{H}_{2}(\mathrm{~g})+1.8448 \mathrm{H}_{2} \mathrm{O}(\mathrm{g})+0.0505 \mathrm{CO}(\mathrm{g})+\right.$ $\left.0.9459 \mathrm{CO}_{2}(\mathrm{~g})+3.7869 \mathrm{Ni}+0.2131 \mathrm{NiO}+0.0036 \mathrm{C}\right)$ at $700^{\circ} \mathrm{C}$. These compositions were compiled in the reaction equation as

$$
\begin{aligned}
\mathrm{CH}_{4}(\mathrm{~g})+4 \mathrm{NiO}= & 0.1554 \mathrm{H}_{2}(\mathrm{~g})+1.8448 \mathrm{H}_{2} \mathrm{O}(\mathrm{g}) \\
& +0.0505 \mathrm{CO}(\mathrm{g})+0.9459 \mathrm{CO}_{2}(\mathrm{~g}) \\
& +3.7869 \mathrm{Ni}+0.2131 \mathrm{NiO}+0.0036 \mathrm{C}
\end{aligned}
$$

This reaction was input to the reaction equations module of HSC Chemistry software, which calculated the reaction enthalpy $(\Delta H)$ as $145.69 \mathrm{~kJ}$ at $700^{\circ} \mathrm{C}$. The data analysis and use of this data for technology development aspects have been discussed in next section.

\section{Results and Discussion}

3.1. Desired Product Yield. The most desired products in CLC of methane are $\mathrm{CO}_{2}$ and $\mathrm{H}_{2} \mathrm{O}$. CLC process conditions to maximise their formation in the CLC fuel reactor are of vital interest for successful technology development. As a preliminary step, the individual $\mathrm{CO}_{2}$ and $\mathrm{H}_{2} \mathrm{O}$ formation in the CLC fuel reactor was studied and discussed in detail in the next section.

3.1.1. $\mathrm{H}_{2} \mathrm{O}$ Yield. The maximum possible $\mathrm{H}_{2} \mathrm{O}$ yield in the CLC fuel reactor for 1 mole methane input is 2 moles of $\mathrm{H}_{2} \mathrm{O}$. Figure 1 shows the variation of $\mathrm{H}_{2} \mathrm{O}$ yield (moles) for CLC of methane fuel reactor within the temperature range from 600 to $1200^{\circ} \mathrm{C}$ at 1 bar pressure. It was observed that the $\mathrm{H}_{2} \mathrm{O}$ yield for selected oxygen carriers showed a mixed trend; that is, for some oxygen carriers, the $\mathrm{H}_{2} \mathrm{O}$ formation 
TABLE 2: Oxygen carrier species used and reduced species considered for each oxygen carrier in CLC process.

\begin{tabular}{|c|c|c|}
\hline Sr. number & $\begin{array}{l}\text { Oxygen } \\
\text { carriers }\end{array}$ & Species considered \\
\hline 1 & $\mathrm{NiO}$ & $\mathrm{NiO}, \mathrm{Ni}(\mathrm{OH})_{2}, \mathrm{Ni}, \mathrm{NiCO}_{3}, \mathrm{H}_{2}(\mathrm{~g}), \mathrm{H}_{2} \mathrm{O}(\mathrm{g}), \mathrm{CH}_{4}(\mathrm{~g}), \mathrm{CO}(\mathrm{g}), \mathrm{CO}_{2}(\mathrm{~g}), \mathrm{C}$ \\
\hline 2 & $\mathrm{Fe}_{2} \mathrm{O}_{3}$ & $\mathrm{Fe}, \mathrm{Fe}_{2} \mathrm{O}_{3}, \mathrm{FeCO}_{3}, \mathrm{FeO}, \mathrm{Fe}_{3} \mathrm{O}_{4}, \mathrm{Fe}(\mathrm{OH})_{2}, \mathrm{Fe}(\mathrm{OH})_{3}, \mathrm{H}_{2}(\mathrm{~g}), \mathrm{H}_{2} \mathrm{O}(\mathrm{g}), \mathrm{CH}_{4}(\mathrm{~g}), \mathrm{CO}(\mathrm{g}), \mathrm{CO}_{2}(\mathrm{~g}), \mathrm{C}$ \\
\hline 3 & $\mathrm{Mn}_{2} \mathrm{O}_{3}$ & $\mathrm{Mn}_{2} \mathrm{O}_{3}, \mathrm{Mn}, \mathrm{MnO}, \mathrm{MnCO}_{3}, \mathrm{Mn}_{3} \mathrm{O}_{4}, \mathrm{Mn}(\mathrm{OH})_{2}, \mathrm{H}_{2}(\mathrm{~g}), \mathrm{H}_{2} \mathrm{O}(\mathrm{g}), \mathrm{CH}_{4}(\mathrm{~g}), \mathrm{CO}(\mathrm{g}), \mathrm{CO}_{2}(\mathrm{~g}), \mathrm{C}$ \\
\hline 4 & $\mathrm{CaSO}_{4}$ & $\mathrm{H}_{2} \mathrm{~S}, \mathrm{SO}_{2}, \mathrm{SO}_{3}, \mathrm{COS}, \mathrm{CaSO}_{4}, \mathrm{CaS}, \mathrm{CaO}, \mathrm{CaCO}_{3}, \mathrm{Ca}(\mathrm{OH})_{2}, \mathrm{CaSO}_{3}, \mathrm{H}_{2}(\mathrm{~g}), \mathrm{H}_{2} \mathrm{O}(\mathrm{g}), \mathrm{CH}_{4}(\mathrm{~g}), \mathrm{CO}(\mathrm{g}), \mathrm{CO}_{2}(\mathrm{~g}), \mathrm{C}$ \\
\hline 5 & $\mathrm{Na}_{2} \mathrm{SO}_{4}$ & $\mathrm{H}_{2} \mathrm{~S}, \mathrm{SO}_{2}, \mathrm{SO}_{3}, \mathrm{Na}_{2} \mathrm{SO}_{4}, \mathrm{COS}, \mathrm{Na}_{2} \mathrm{CO}_{3}, \mathrm{Na}_{2} \mathrm{~S}, \mathrm{Na}_{2} \mathrm{O}, \mathrm{Na}_{2} \mathrm{SO}_{3}, \mathrm{NaOH}, \mathrm{H}_{2}(\mathrm{~g}), \mathrm{H}_{2} \mathrm{O}(\mathrm{g}), \mathrm{CH}_{4}(\mathrm{~g}), \mathrm{CO}(\mathrm{g}), \mathrm{CO}_{2}(\mathrm{~g}), \mathrm{C}$ \\
\hline 6 & $\mathrm{CoO}$ & $\mathrm{Co}, \mathrm{CoCO}_{3}, \mathrm{CoO}, \mathrm{Co}(\mathrm{OH})_{2}, \mathrm{H}_{2}(\mathrm{~g}), \mathrm{H}_{2} \mathrm{O}(\mathrm{g}), \mathrm{CH}_{4}(\mathrm{~g}), \mathrm{CO}(\mathrm{g}), \mathrm{CO}_{2}(\mathrm{~g}), \mathrm{C}$ \\
\hline 7 & $\mathrm{CuO}$ & $\mathrm{CuOH}, \mathrm{Cu}(\mathrm{OH})_{2}, \mathrm{Cu}, \mathrm{CuCO}_{3}, \mathrm{CuO}, \mathrm{Cu}_{2} \mathrm{O}, \mathrm{H}_{2}(\mathrm{~g}), \mathrm{H}_{2} \mathrm{O}(\mathrm{g}), \mathrm{CH}_{4}(\mathrm{~g}), \mathrm{CO}(\mathrm{g}), \mathrm{CO}_{2}(\mathrm{~g}), \mathrm{C}$ \\
\hline
\end{tabular}

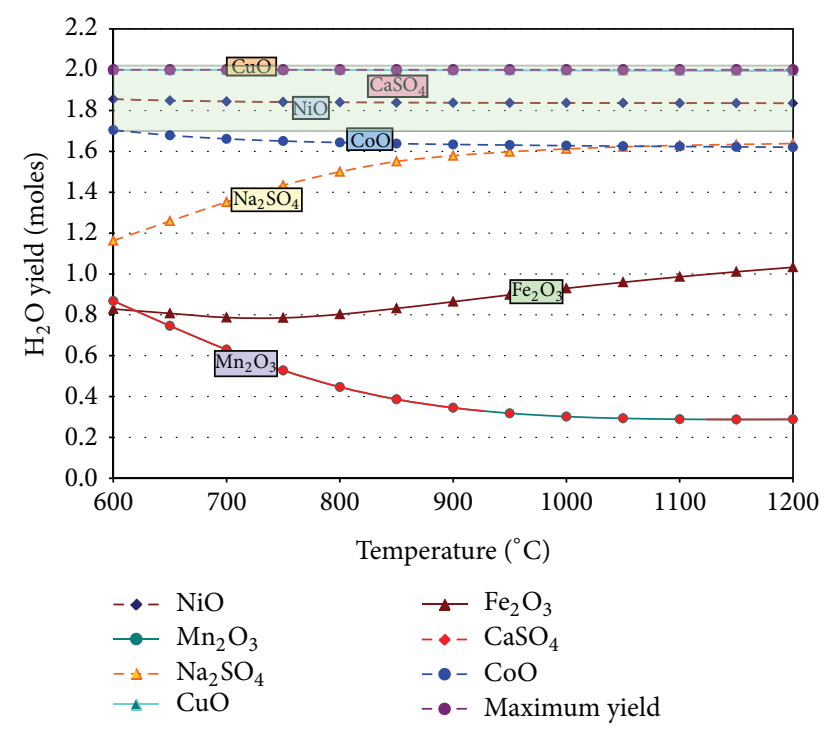

FIGURE 1: $\mathrm{H}_{2} \mathrm{O}$ yield for CLC of methane.

increased with increase in temperature, while in other cases, the $\mathrm{H}_{2} \mathrm{O}$ yield decreased with increase in temperature. From the figure, it was seen that the moles of $\mathrm{H}_{2} \mathrm{O}$ slightly decreased from 1.85 to 1.83 moles with increase in temperature from $600^{\circ} \mathrm{C}$ to $1200^{\circ} \mathrm{C}$ for $\mathrm{NiO}$. The same trend was observed for $\mathrm{CoO}$; that is, it decreased from 1.705 to 1.62 moles. But the $\mathrm{H}_{2} \mathrm{O}$ yield increased from 1.80 to 1.89 moles up to $850^{\circ} \mathrm{C}$ then it decreased to 1.81 moles $\left(1200^{\circ} \mathrm{C}\right)$ for $\mathrm{CaSO}_{4}$, while the $\mathrm{H}_{2} \mathrm{O}$ yield increased with increase in temperature (i.e., 1.16 at $600^{\circ} \mathrm{C}$ to 1.64 at $1200^{\circ} \mathrm{C}$ ) for $\mathrm{Na}_{2} \mathrm{SO}_{4}$. It was also observed that the $\mathrm{H}_{2} \mathrm{O}$ yield first decreased from 0.83 to 0.78 moles up to $750^{\circ} \mathrm{C}$ and then increased to 1.03 moles for $\mathrm{Fe}_{2} \mathrm{O}_{3}$. However, the $\mathrm{H}_{2} \mathrm{O}$ yield remained almost constant at all temperatures (that was the maximum moles of $\mathrm{H}_{2} \mathrm{O}$ obtainable) for $\mathrm{CuO}$ when compared to all other oxygen carriers (e.g., 1.99 moles at $600^{\circ} \mathrm{C}$ and 1.99 moles at $1200^{\circ} \mathrm{C}$ ). But the $\mathrm{H}_{2} \mathrm{O}$ yield decreased from 0.87 to 0.29 moles with increase in temperature from 600 to $1200^{\circ} \mathrm{C}$ for $\mathrm{Mn}_{2} \mathrm{O}_{3}$. The minimum moles of $\mathrm{H}_{2} \mathrm{O}$ produced were 0.29 moles for $\mathrm{Mn}_{2} \mathrm{O}_{3}$ at $1200^{\circ} \mathrm{C}$, while the maximum $\mathrm{H}_{2} \mathrm{O}$ moles produced were 2.00 for $\mathrm{CuO}$ at $600^{\circ} \mathrm{C}$. The ranking of oxygen carriers with respect to increasing order of moles of $\mathrm{H}_{2} \mathrm{O}$ produced

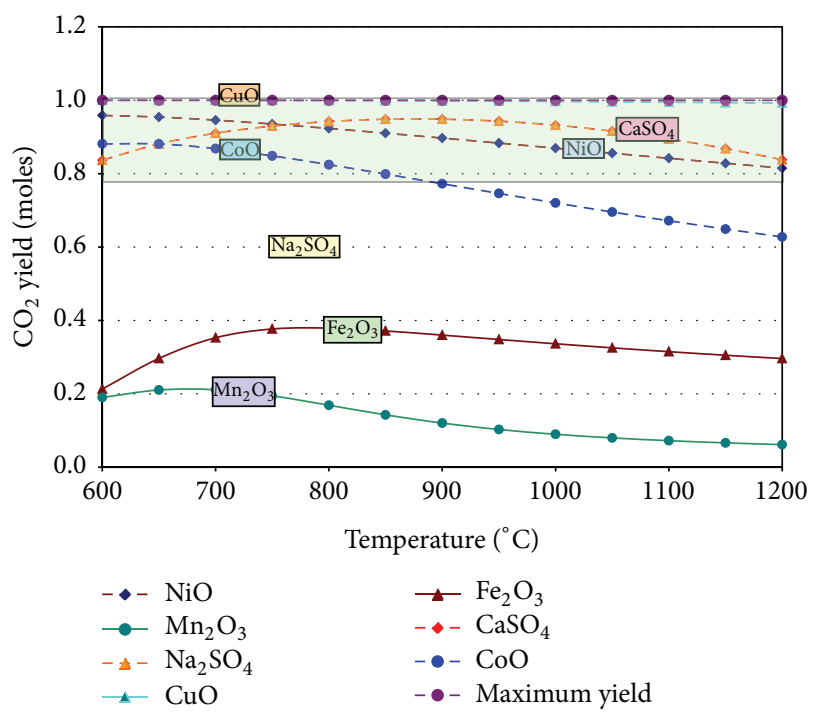

Figure 2: $\mathrm{CO}_{2}$ yield for CLC of methane.

from methane was found to be as follows: $\mathrm{CuO}\left(1.99,600^{\circ} \mathrm{C}\right)>$ $\mathrm{CaSO}_{4}\left(1.89,850^{\circ} \mathrm{C}\right)>\mathrm{NiO}\left(1.86,600^{\circ} \mathrm{C}\right)>\mathrm{CoO}\left(1.70,600^{\circ} \mathrm{C}\right)$ $>\mathrm{Na}_{2} \mathrm{SO}_{4}\left(1.64,1200^{\circ} \mathrm{C}\right)>\mathrm{Fe}_{2} \mathrm{O}_{3}\left(1.03,1200^{\circ} \mathrm{C}\right)>\mathrm{Mn}_{2} \mathrm{O}_{3}$ $\left(0.87,600^{\circ} \mathrm{C}\right)$.

3.1.2. $\mathrm{CO}_{2}$ Yield. Similarly, the effect of temperature and oxygen carrier on $\mathrm{CO}_{2}$ formation in the CLC fuel reactor was studied. The net $\mathrm{CO}_{2}$ obtainable in the CLC fuel reactor was 1 mole per mole of methane feed. The trends in the $\mathrm{CO}_{2}$ formation with selected oxygen carriers are shown in Figure 2. It was observed that the $\mathrm{CO}_{2}$ yield also showed mixed trends (similar to $\mathrm{H}_{2} \mathrm{O}$ ) for different oxygen carriers with increase in temperature from 600 to $1200^{\circ} \mathrm{C}$. The maximum $\mathrm{CO}_{2}$ yield in CLC fuel reactor was 1.00 mole for its reaction with $\mathrm{CuO}$ at $600^{\circ} \mathrm{C}$, while the minimum $\mathrm{CO}_{2}$ yield of 0.06 moles for $\mathrm{Mn}_{2} \mathrm{O}_{3}$ was calculated at $1200^{\circ} \mathrm{C}$. The selectivity of the oxygen carriers based on maximum $\mathrm{CO}_{2}$ yield (moles) was analysed and was found to be as follows: $\mathrm{CuO}\left(1.00,600^{\circ} \mathrm{C}\right)>\mathrm{NiO}$ $\left(0.96,600^{\circ} \mathrm{C}\right)>\mathrm{CaSO}_{4}\left(0.95,900^{\circ} \mathrm{C}\right)>\mathrm{CoO}\left(0.88,600^{\circ} \mathrm{C}\right)>$ $\mathrm{Na}_{2} \mathrm{SO}_{4}\left(0.71,1050^{\circ} \mathrm{C}\right)>\mathrm{Fe}_{2} \mathrm{O}_{3}\left(0.38,800^{\circ} \mathrm{C}\right)>\mathrm{Mn}_{2} \mathrm{O}_{3}(0.21$, $700^{\circ} \mathrm{C}$ ). 
3.1.3. $\left(\mathrm{H}_{2} \mathrm{O}+\mathrm{CO}_{2}\right)$ Yield. It was clearly seen that the ranking of the oxygen carriers with their suitable operating temperatures was not the same for both major products. Hence, selection of the optimum process conditions was done by using a different parameter. In this case, the combined desired product $\left(\mathrm{H}_{2} \mathrm{O}\right.$ and $\left.\mathrm{CO}_{2}\right)$ yield from the CLC fuel reactor is considered as a better parameter than individual yields. The maximum yield of 3 moles $\left(1\right.$ mole $\mathrm{CO}_{2}+2$ moles $\mathrm{H}_{2} \mathrm{O}$ ) can be obtained from one mole methane in the CLC fuel reactor. The combined yields of $\mathrm{H}_{2} \mathrm{O}$ and $\mathrm{CO}_{2}$ were plotted in Figure 3 for selected oxygen carriers in the considered temperature range. It was observed that similar to the individual $\mathrm{H}_{2} \mathrm{O}$ and $\mathrm{CO}_{2}$ yields, the oxygen carriers showed different trends for combined yield $\left(\mathrm{CO}_{2}+\right.$ $\mathrm{H}_{2} \mathrm{O}$ ) with increase in CLC fuel reactor temperature. It was observed that the $\left(\mathrm{CO}_{2}+\mathrm{H}_{2} \mathrm{O}\right)$ yield for $\mathrm{NiO}$ decreased from 2.81 to 2.65 moles with increase in temperature from 600 to $1200^{\circ} \mathrm{C}$ as reported earlier [42]. Similar trend was observed for $\mathrm{Mn}_{2} \mathrm{O}_{3}$ and $\mathrm{CoO}$, where the $\left(\mathrm{CO}_{2}+\mathrm{H}_{2} \mathrm{O}\right)$ yield decreased from 2.59 to 2.25 moles for $\mathrm{CoO}$ and from 1.06 moles to 0.35 moles for $\mathrm{Mn}_{2} \mathrm{O}_{3}$ with increase in temperature from 600 to $1200^{\circ} \mathrm{C}$. The $\left(\mathrm{CO}_{2}+\mathrm{H}_{2} \mathrm{O}\right)$ yield increased from 1.45 to 2.34 moles up to $1100^{\circ} \mathrm{C}$, and then it remained almost constant till $1200^{\circ} \mathrm{C}$ for $\mathrm{Na}_{2} \mathrm{SO}_{4}$. The $\left(\mathrm{CO}_{2}+\mathrm{H}_{2} \mathrm{O}\right)$ yield increased with increase in temperature, that is, from 1.04 moles $\left(600^{\circ} \mathrm{C}\right)$ to 1.33 moles $\left(1200^{\circ} \mathrm{C}\right)$ for $\mathrm{Fe}_{2} \mathrm{O}_{3}$, while for $\mathrm{CaSO}_{4}$, the $\left(\mathrm{CO}_{2}+\mathrm{H}_{2} \mathrm{O}\right)$ yield increased from 2.64 to 2.84 moles up to $850^{\circ} \mathrm{C}$ and then decreased to 2.65 moles at $1200^{\circ} \mathrm{C}$. In case of $\mathrm{CuO}$, the $\left(\mathrm{CO}_{2}+\mathrm{H}_{2} \mathrm{O}\right)$ yield remained almost constant at all temperatures, that is, 3.00 moles. A maximum $\left(\mathrm{CO}_{2}+\mathrm{H}_{2} \mathrm{O}\right)$ yield of 3.00 moles was obtained with $\mathrm{CuO}$ at almost all temperatures, while the minimum $\left(\mathrm{CO}_{2}+\mathrm{H}_{2} \mathrm{O}\right)$ yield of 0.35 moles was observed for $\mathrm{Mn}_{2} \mathrm{O}_{3}$ at $1200^{\circ} \mathrm{C}$. The ranking of oxygen carriers based on the maximum $\left(\mathrm{CO}_{2}\right.$ $\left.+\mathrm{H}_{2} \mathrm{O}\right)$ yield was seen as follows: $\mathrm{CuO}\left(2.99,600^{\circ} \mathrm{C}\right)>$ $\mathrm{CaSO}_{4}\left(2.84,850^{\circ} \mathrm{C}\right)>\mathrm{NiO}\left(2.81,600^{\circ} \mathrm{C}\right)>\mathrm{CoO}\left(2.59,600^{\circ} \mathrm{C}\right)$ $>\mathrm{Na}_{2} \mathrm{SO}_{4}\left(2.34,1100^{\circ} \mathrm{C}\right)>\mathrm{Fe}_{2} \mathrm{O}_{3}\left(1.33,1200^{\circ} \mathrm{C}\right)>\mathrm{Mn}_{2} \mathrm{O}_{3}$ $\left(1.06,600^{\circ} \mathrm{C}\right)$. This combined product criterion for selection of oxygen carriers and process temperature was useful for process operation.

3.2. Undesired Product Formation. Some undesired products are also formed in the CLC fuel reactor due to side reactions and thermodynamic limitations under the CLC conditions. An estimation of the nature and amount of the byproducts is important for technology development and hence was studied in detail.

3.2.1. Syngas $\left(\mathrm{H}_{2}+\mathrm{CO}\right)$ Formation. Syngas $\left(\mathrm{H}_{2}+\mathrm{CO}\right)$ is one of the undesired products of the CLC process. The data of syngas formation in the CLC fuel reactor with selected oxygen carriers within the temperature range from 600 to $1200^{\circ} \mathrm{C}$ was analyzed and is shown in Figure 4 . From the figure, it was observed that the syngas formation increased with increase in process temperature from 600 to $1200^{\circ} \mathrm{C}$ for all oxygen carriers except for $\mathrm{Fe}_{2} \mathrm{O}_{3}$, where it was slightly decreased at higher temperature. The syngas formation (moles) increased from 1.13 to $2.64\left(\mathrm{Mn}_{2} \mathrm{O}_{3}\right), 0.35$

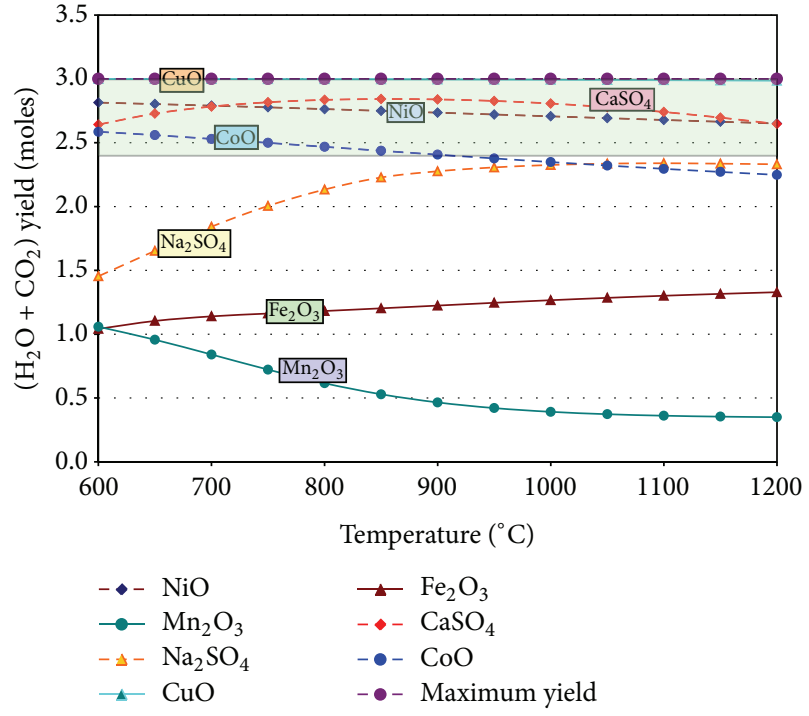

Figure 3: $\left(\mathrm{H}_{2} \mathrm{O}+\mathrm{CO}_{2}\right)$ yield for CLC of methane.

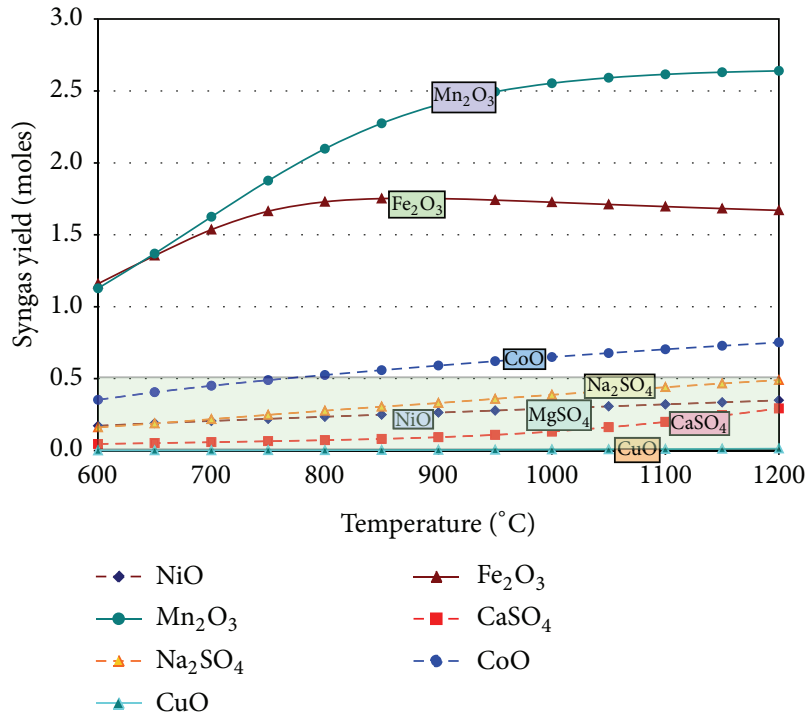

FIGURE 4: Syngas formation for CLC of methane.

to $0.75(\mathrm{CoO}), 0.17$ to $0.35(\mathrm{NiO}), 0.16$ to $0.49\left(\mathrm{Na}_{2} \mathrm{SO}_{4}\right)$, 0.05 to $0.29\left(\mathrm{CaSO}_{4}\right)$, and 0.00 to 0.01 moles $(\mathrm{CuO})$ with increase in temperature from 600 to $1200^{\circ} \mathrm{C}$. But it was also seen that the syngas formation increased from 1.16 to 1.75 moles up to $900^{\circ} \mathrm{C}$ and then slightly decreased to 1.67 moles at $1200^{\circ} \mathrm{C}$ in the case of $\mathrm{Fe}_{2} \mathrm{O}_{3} . \mathrm{CuO}$ produced negligible syngas when compared to all other oxygen carriers at all temperatures. The minimum syngas moles produced were negligible for $\mathrm{CuO}$, while the maximum syngas of 2.64 moles was produced by $\mathrm{Mn}_{2} \mathrm{O}_{3}$ at $1200^{\circ} \mathrm{C}$ in this study. The ranking of the oxygen carriers based on minimum syngas production (moles) in the CLC fuel reactor was observed as follows: $\mathrm{CuO}(0.00)>\mathrm{CaSO}_{4}(0.05)>\mathrm{Na}_{2} \mathrm{SO}_{4}(0.16)>$ $\mathrm{NiO}(0.17)>\mathrm{CoO}(0.35)>\mathrm{Mn}_{2} \mathrm{O}_{3}(1.13)>\mathrm{Fe}_{2} \mathrm{O}_{3}(1.16)$ at $600^{\circ} \mathrm{C}$. 


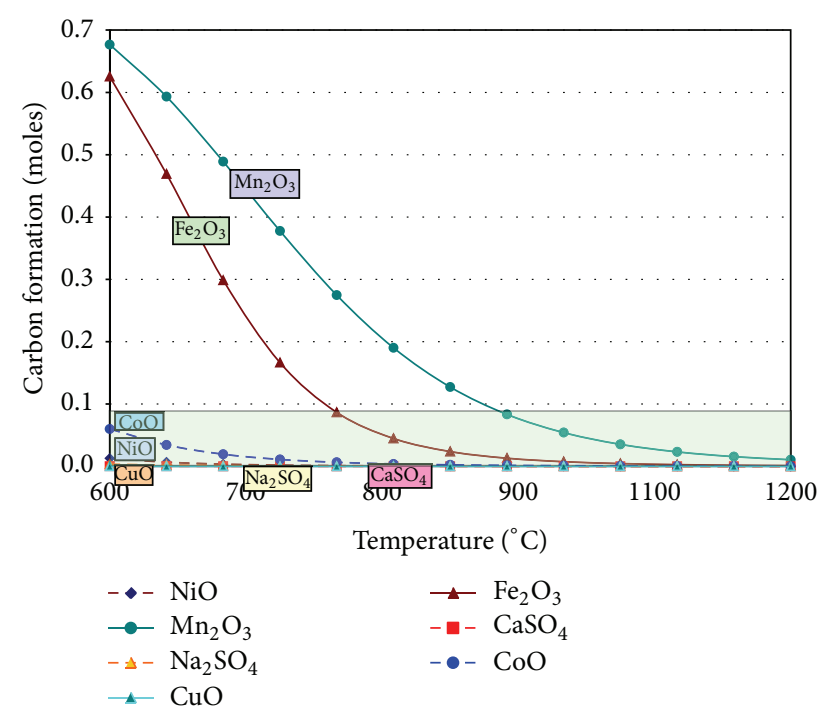

FIGURE 5: Carbon formation for CLC of methane.

3.2.2. Carbon Formation. Carbon formation is undesirable in the CLC process as coking may reduce the activity of the solid oxygen carriers. Figure 5 shows the carbon formation in the CLC fuel reactor for methane fuel within the temperature range of $600^{\circ} \mathrm{C}$ to $1200^{\circ} \mathrm{C}$ at 1 bar pressure. From the figure, it was observed that the carbon formation was higher at lower temperatures (till $\sim 700^{\circ} \mathrm{C}$ ) due to carbon formation side reactions (5), (6), and (7). It was also seen that the carbon formation decreased with increase in temperature from 600 to $1200^{\circ} \mathrm{C}$ for all oxygen carriers except for $\mathrm{CuO}$ (as found earlier [1]) and $\mathrm{CaSO}_{4}$ as it was almost zero at all temperatures. The carbon formation steeply decreased from 0.68 at $600^{\circ} \mathrm{C}$ to 0.010 at $1200^{\circ} \mathrm{C}$ for $\mathrm{Mn}_{2} \mathrm{O}_{3}$, while it decreased from 0.63 to 0.001 moles for $\mathrm{Fe}_{2} \mathrm{O}_{3}$. The carbon formation slightly decreased with increase in temperature, that is, from 0.06 moles at $600^{\circ} \mathrm{C}$ to 0.00 at $1200^{\circ} \mathrm{C}$ for $\mathrm{CoO}$. The carbon formation also decreased from 0.013 moles to $0.00(\mathrm{NiO})$, from 0.003 moles to $0.00\left(\mathrm{Na}_{2} \mathrm{SO}_{4}\right)$ within 600 to $1200^{\circ} \mathrm{C}$. $\mathrm{Fe}_{2} \mathrm{O}_{3}$ and $\mathrm{Mn}_{2} \mathrm{O}_{3}$ produced higher carbon in comparison with the rest of the oxygen carriers at the same temperatures. The maximum carbon yield was 0.68 moles with $\mathrm{Mn}_{2} \mathrm{O}_{3}$ at $600^{\circ} \mathrm{C}$. This solid carbon can be separated from gas stream but cannot be separated from the oxygen carrier, and it is carried to the air reactor where it is oxidised to $\mathrm{CO}_{2}$. This combustion generates energy but also contaminates the $\mathrm{N}_{2}$ stream from the air reactor with some $\mathrm{CO}_{2}$ and increases the air requirement in CLC air reactor. It was seen that all oxygen carriers gave their maximum carbon yield at $600^{\circ} \mathrm{C}$. The selectivity of the oxygen carrier as per the decreasing yield of carbon (in moles) is observed as follows: $\mathrm{Mn}_{2} \mathrm{O}_{3}(0.677)<\mathrm{Fe}_{2} \mathrm{O}_{3}(0.625)<\mathrm{CoO}(0.06)<\mathrm{NiO}$ $(0.013)<\mathrm{Na}_{2} \mathrm{SO}_{4}(0.003)<\mathrm{CaSO}_{4}(0.0002)<\mathrm{CuO}(0.00)$ at $600^{\circ} \mathrm{C}$.

3.2.3. $\mathrm{SO}_{2}$ and $\mathrm{H}_{2} \mathrm{~S}$ Formation. The possibility of $\mathrm{SO}_{2}, \mathrm{COS}$, and $\mathrm{H}_{2} \mathrm{~S}$ formation in the CLC fuel reactor while using sulphates as oxygen carriers was also considered in this study,

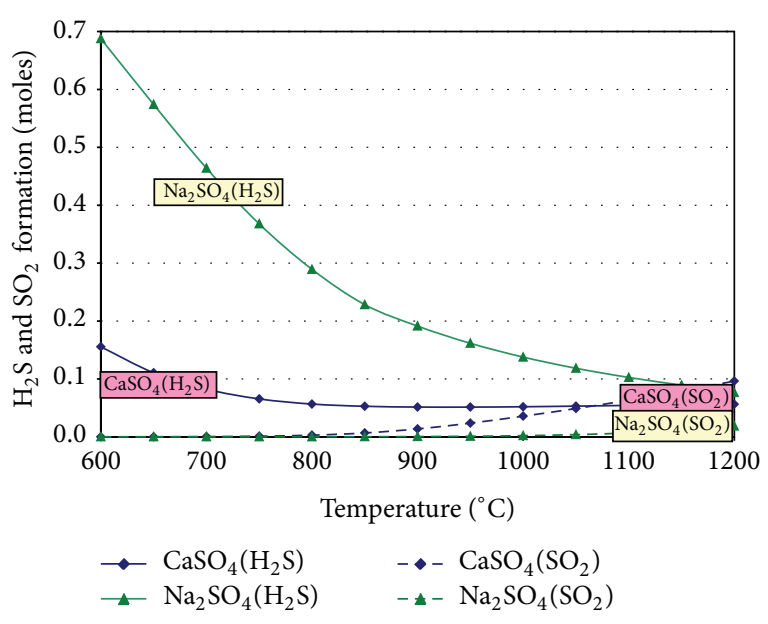

FiguRE 6: $\mathrm{H}_{2} \mathrm{~S}$ and $\mathrm{SO}_{2}$ gases formation for CLC of methane.

as it was reported by other researchers $[79,80]$. Both $\mathrm{SO}_{2}$ and $\mathrm{H}_{2} \mathrm{~S}$ are highly undesirable for the process. The results showed that $\mathrm{SO}_{2}$ and $\mathrm{H}_{2} \mathrm{~S}$ formation takes place in the CLC fuel reactor.

Figure 6 shows the $\mathrm{H}_{2} \mathrm{~S}$ and $\mathrm{SO}_{2}$ formation for the 3 sulphate-based oxygen carriers within the temperature range from 600 to $1200^{\circ} \mathrm{C}$ at 1 bar pressure per mole methane used in the feed. It was observed that the $\mathrm{H}_{2} \mathrm{~S}$ formation decreased with increase in temperature for all sulphates. The $\mathrm{H}_{2} \mathrm{~S}$ formation (moles) decreased from 0.16 to 0.06 for $\mathrm{CaSO}_{4}$ and from 0.69 to 0.08 moles for $\mathrm{Na}_{2} \mathrm{SO}_{4}$ with increase in temperature from 600 to $1200^{\circ} \mathrm{C}$. The maximum $\mathrm{H}_{2} \mathrm{~S}$ yield was found to be 0.69 moles at $600^{\circ} \mathrm{C}$ for $\mathrm{Na}_{2} \mathrm{SO}_{4}$, while the minimum $\mathrm{H}_{2} \mathrm{~S}$ yield was found to be 0.06 moles at $1200^{\circ} \mathrm{C}$ for $\mathrm{CaSO}_{4}$. Figure 6 also showed that the $\mathrm{SO}_{2}$ formation increased with increase in temperature for all sulphates. The $\mathrm{SO}_{2}$ formation increased from 0.00 to 0.1 moles for $\mathrm{CaSO}_{4}$ and from 0.00 to 0.02 moles for $\mathrm{Na}_{2} \mathrm{SO}_{4}$ with increase in temperature from 600 to $1200^{\circ} \mathrm{C}$. The maximum $\mathrm{SO}_{2}$ yield was found to be 0.1 moles at $1200^{\circ} \mathrm{C}$ for $\mathrm{CaSO}_{4}$, while zero $\mathrm{SO}_{2}$ formation was observed at lower temperatures till $850^{\circ} \mathrm{C}$ for $\mathrm{Na}_{2} \mathrm{SO}_{4}$ and till $650^{\circ} \mathrm{C}$ for $\mathrm{CaSO}_{4}$. Hence, according to the data analysis, the choice of better oxygen carrier amongst sulphates was $\mathrm{CaSO}_{4}>\mathrm{Na}_{2} \mathrm{SO}_{4} . \mathrm{H}_{2} \mathrm{~S}$ or $\mathrm{SO}_{2}$ formation reduces the sulphate to its oxide (e.g., $\mathrm{CaO}$ and $\mathrm{Na}_{2} \mathrm{O}$ ), which can be regenerated by using an acid but may require additional processing cost. Commercial systems to trap $\mathrm{SO}_{2}$ as well as $\mathrm{H}_{2} \mathrm{~S}$ are available; however, deterioration of sulphate-based oxygen carrier is always a matter of greater concern. Depending on the cost and availability of the sulphate, smart choice of sulphate oxygen carrier can be made.

3.3. Reactant Conversions. A study of conversion of the reactants is also important for CLC technology development and hence studied in detail and discussed in the following section.

3.3.1. $\mathrm{CH}_{4}$ Conversion. Methane conversion in the CLC fuel reactor is one of the important aspects for choosing the 


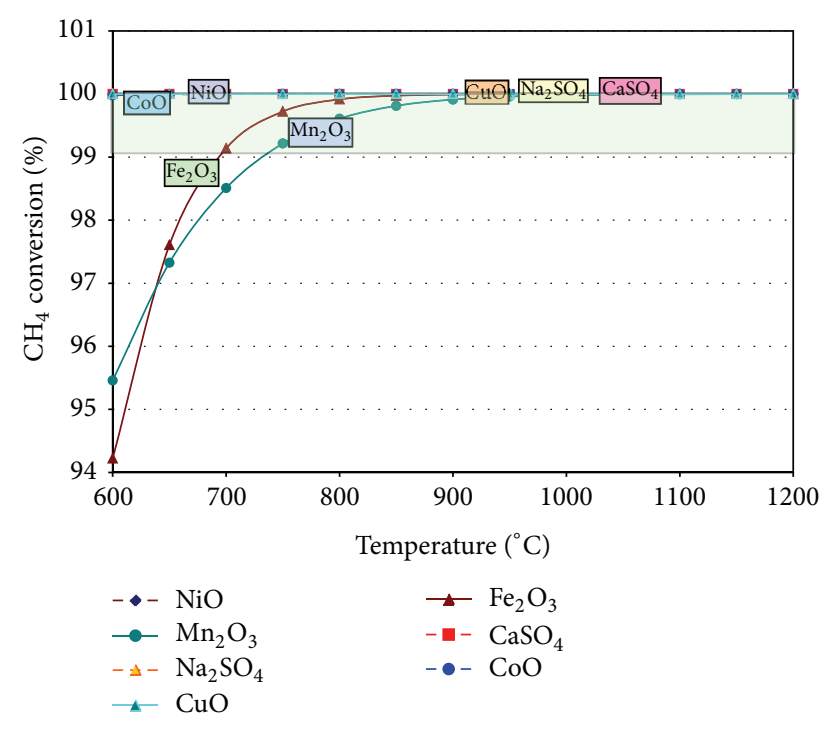

FIGURE 7: $\mathrm{CH}_{4}$ conversion for CLC of methane.

oxygen carrier and operating temperature range, as the reactivity of oxygen carriers with methane may be different. Figure 7 depicts the trends in $\mathrm{CH}_{4}$ conversion with increase in temperature from 600 to $1200^{\circ} \mathrm{C}$ at 1 bar pressure for the selected oxygen carriers. It was observed from Figure 7 that the $\mathrm{CH}_{4}$ conversion was almost $100 \%$ for all oxygen carriers except for $\mathrm{Fe}_{2} \mathrm{O}_{3}$ and $\mathrm{Mn}_{2} \mathrm{O}_{3}$, where lower methane conversion was seen at lower temperatures. The $\mathrm{CH}_{4}$ conversion increased from $94.22 \%$ to $100 \%$ for $\mathrm{Fe}_{2} \mathrm{O}_{3}$, while it was increased from $95.46 \%$ to $100 \%$ for $\mathrm{Mn}_{2} \mathrm{O}_{3}$ (also experimentally demonstrated earlier [81]), with increase in CLC fuel reactor temperature from 600 to $1200^{\circ} \mathrm{C}$. Complete conversion of $\mathrm{CH}_{4}$ was achieved for all oxygen carriers in the conditions considered in this study, as these oxygen carriers gave almost $100 \%$ methane conversion above $800^{\circ} \mathrm{C}$ only.

3.3.2. Oxygen Carrier Reduction. The reduction of oxygen carrier in the fuel reactor is a key reaction responsible for oxygen availability in CLC reaction and is controlled by the thermodynamic limitations. A study of oxygen carrier conversions in the fuel reactor is also important for calculating the air requirement for regeneration of the oxygen carrier. Hence, all possible reduced states of the oxygen carrier were considered in this study. It was observed that oxygen carriers like $\mathrm{NiO}, \mathrm{CuO}$, and $\mathrm{CoO}$ were reduced to their respective metals in the fuel reactor. However, oxygen carriers like $\mathrm{Fe}_{2} \mathrm{O}_{3}$ and $\mathrm{Mn}_{2} \mathrm{O}_{3}$ were reduced to different reduced states. Similarly, many other species were also formed with the sulfate oxygen carriers in the CLC fuel reactor. The species formed in the CLC fuel reactor of $\mathrm{Fe}_{2} \mathrm{O}_{3}$ and $\mathrm{CaSO}_{4}$ were discussed in detail.

3.3.3. Reduced Species of $\mathrm{Fe}_{2} \mathrm{O}_{3}$. Figure 8(a) shows the different reduced species of $\mathrm{Fe}_{2} \mathrm{O}_{3}$ for CLC of methane in the temperature range from 600 to $1200^{\circ} \mathrm{C}$ at 1 bar pressure. From the figure, it was observed that $\mathrm{Fe}_{2} \mathrm{O}_{3}$ was almost reduced completely into its different reduced species like $\mathrm{Fe}, \mathrm{FeO}$, and $\mathrm{Fe}_{3} \mathrm{O}_{4}$. The moles of $\mathrm{FeO}$ and $\mathrm{Fe}$ produced increased with increase in temperature; that is, for $\mathrm{FeO}$, it increased from 0.99 to 1.31 moles and for $\mathrm{Fe}$, it increased from 0.44 to 1.08 moles, while the moles of $\mathrm{Fe}_{3} \mathrm{O}_{4}$ produced decreased with increase in temperature; that is, it decreased from 0.41 to 0.09 moles, while negligible amount of $\mathrm{Fe}_{2} \mathrm{O}_{3}$ was observed remaining at all temperatures.

3.3.4. Reduced Species of $\mathrm{CaSO}_{4}$. Figure 8(b) shows the different reduced species of $\mathrm{CaSO}_{4}$ for CLC of methane process in the temperature range from 600 to $1200^{\circ} \mathrm{C}$ at 1 bar pressure. Reduction behaviour of sulphur containing oxygen carrier is even more important due to the possibility of formation of sulphur-based compounds. From Figure 8(b), it was observed that $\mathrm{CaSO}_{4}$ almost reduced completely into its different species like $\mathrm{CaS}, \mathrm{CaO}, \mathrm{CaCO}_{3}, \mathrm{Ca}(\mathrm{OH})_{2}, \mathrm{COS}$, $\mathrm{H}_{2} \mathrm{~S}$, and $\mathrm{SO}_{2}$. The moles of $\mathrm{SO}_{2}$ and $\mathrm{CaO}$ produced were increased with increase in temperature; that is, it increased from 0.00 to 0.1 moles for $\mathrm{SO}_{2}$ and increased from 0.00 to 0.15 moles for $\mathrm{CaO}$, while moles of $\mathrm{CaCO}_{3}$ produced decreased with increase in temperature; that is, it decreased from 0.15 moles to its lowest value. Moles of $\mathrm{H}_{2} \mathrm{~S}$ produced decreased till $950^{\circ} \mathrm{C}$, and then slightly increased with increase in temperature; that is, it decreased from 0.16 to 0.05 moles and then increased to 0.06 moles while reverse trend was observed for $\mathrm{CaS}$, that is, moles of $\mathrm{CaS}$ produced increased till $850^{\circ} \mathrm{C}$ and then slightly decreased with increase in temperature, for example, it increased from 0.83 to 0.93 moles and then decreased to 0.84 moles. CaS being the most desirable reduced state, the CLC fuel reactor temperature can be limited to $950^{\circ} \mathrm{C}$ when $\mathrm{CaSO}_{4}$ is used as oxygen carrier. Negligible amount of $\mathrm{COS}$ and $\mathrm{Ca}(\mathrm{OH})_{2}$ formation was observed with increase in temperature.

It was observed that the sulfate oxygen carriers suffer losses due to conversion to the oxide and carbonate in the CLC fuel reactor. The oxide and carbonate cannot be separated from the solid stream in continuous operation. Hence, a small amount of sulfate oxygen carrier needs to be added to the process continuously to keep the amount of active oxygen carrier intact. This will also require a continuous small purge of the spent oxygen carrier from the system to avoid overloading of the system. This purged oxygen carrier can be reacted with dilute $\mathrm{H}_{2} \mathrm{SO}_{4}$, filtered, and dried to convert the oxide and carbonate back to the sulfate for reuse in the system. This modification will be governed by the throughput of the CLC plant, operating cost, and cost of the oxygen carrier.

3.4. Process Energy. The CLC system consists of two reactors in which energy and oxygen carrier transfer occurs between the exothermic (air) reactor and the endothermic (fuel) reactor. It is generally considered that the magnitude of energy obtained in CLC is same as the energy of combustion of the fuel. However, the energy obtainable in CLC depends on the conversion of fuel to different products at different temperatures. As seen in the earlier sections, some other 


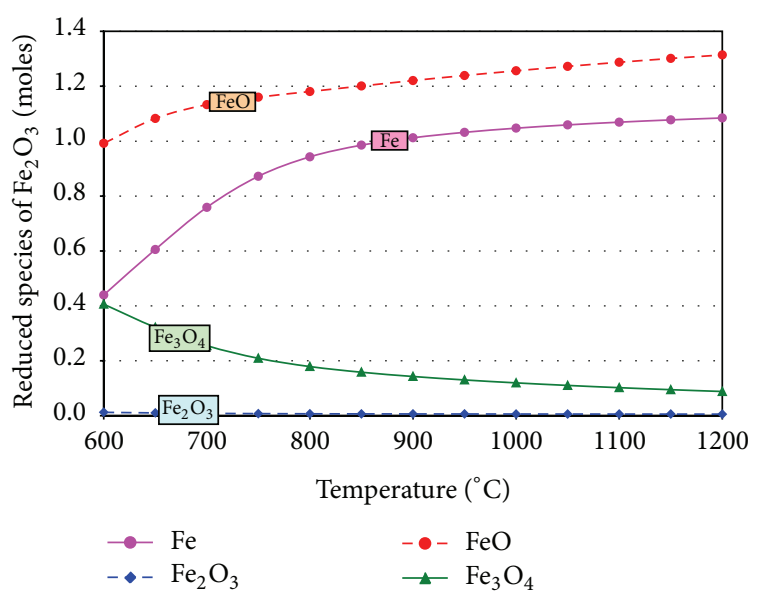

(a)

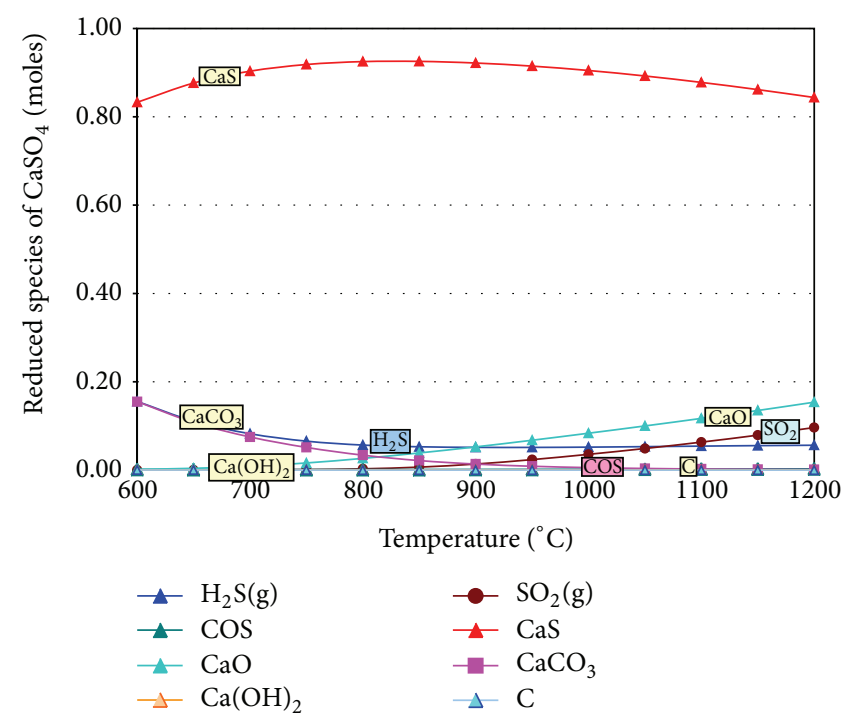

(b)

Figure 8: (a) Reduced species of $\mathrm{Fe}_{2} \mathrm{O}_{3}$ for CLC of methane. (b) Reduced species of $\mathrm{CaSO}_{4}$ for CLC of methane.

byproducts are also formed in the CLC fuel reactor apart from $\mathrm{CO}_{2}$ and $\mathrm{H}_{2} \mathrm{O}$. This affects the net energy obtainable from the CLC system for the different oxygen carriers. The study of fuel and air reactor enthalpy trends within the selected temperature range from 600 to $1200^{\circ} \mathrm{C}$ was essential to calculate the optimum conditions and is discussed in the next section.

3.4.1. Enthalpy of the Fuel Reactor. Methane undergoes oxidation in the fuel reactor generating primarily $\mathrm{CO}_{2}$ and $\mathrm{H}_{2} \mathrm{O}$, and the oxygen carrier is reduced to its lower oxidation state. The enthalpy of this reaction is plotted against temperature in Figure 9 for different oxygen carriers, based on the equilibrium compositions obtained at those conditions. The CLC fuel reactor enthalpy showed different trends for different oxygen carriers. It was observed that the fuel reactor enthalpy increased with increase in temperature from 600 to $1200^{\circ} \mathrm{C}$ for $\mathrm{CoO}(135.15 \mathrm{~kJ}$ to $156.22 \mathrm{~kJ})$, while it increased till $\sim 1100^{\circ} \mathrm{C}$ and then became almost constant with further increase in temperature for $\mathrm{Fe}_{2} \mathrm{O}_{3}$, $\mathrm{Mn}_{2} \mathrm{O}_{3}$, and $\mathrm{CaSO}_{4}$; that is, it increased from $150.09 \mathrm{~kJ}$ to $263.04 \mathrm{~kJ}$ and remained almost constant $\left(\mathrm{Fe}_{2} \mathrm{O}_{3}\right)$, increased from $30.66 \mathrm{~kJ}$ to $124.41 \mathrm{~kJ}$ and remained almost constant $\left(\mathrm{Mn}_{2} \mathrm{O}_{3}\right.$ ), and also increased from $137.42 \mathrm{~kJ}$ to $161.80 \mathrm{~kJ}$ (from 600 to $1150^{\circ} \mathrm{C}$ ) and remained almost constant for $\mathrm{CaSO}_{4}$. However, the reaction enthalpy decreased with increase in temperature in the case of $\mathrm{NiO}$, where it decreased from $146.33 \mathrm{~kJ}\left(600^{\circ} \mathrm{C}\right)$ to $139.61 \mathrm{~kJ}\left(1200^{\circ} \mathrm{C}\right)$. The reaction enthalpy showed some increase-decrease trend with increase in temperature for $\mathrm{CuO}$ and $\mathrm{Na}_{2} \mathrm{SO}_{4}$ as shown in the figure. The ranking of oxygen carriers based on the minimum fuel reactor enthalpy is as follows: $\mathrm{Fe}_{2} \mathrm{O}_{3}\left(263.04 \mathrm{~kJ}, 1100^{\circ} \mathrm{C}\right)<$ $\mathrm{Na}_{2} \mathrm{SO}_{4}\left(194.90 \mathrm{~kJ}, 1200^{\circ} \mathrm{C}\right)<\mathrm{CaSO}_{4}\left(161.80 \mathrm{~kJ}, 1150^{\circ} \mathrm{C}\right)<$ $\mathrm{CoO}\left(156.22 \mathrm{~kJ}, 1200^{\circ} \mathrm{C}\right)<\mathrm{NiO}\left(146.33 \mathrm{~kJ}, 600^{\circ} \mathrm{C}\right)<\mathrm{Mn}_{2} \mathrm{O}_{3}$ $\left(124.41 \mathrm{~kJ}, 1100^{\circ} \mathrm{C}\right)<\mathrm{CuO}\left(-161.48 \mathrm{~kJ}, 1100^{\circ} \mathrm{C}\right)$. However, it

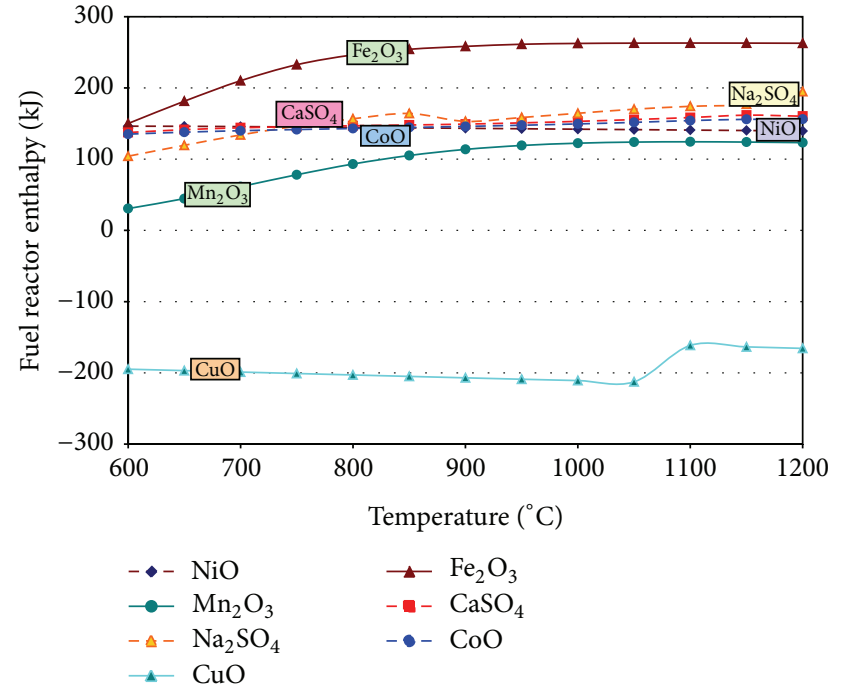

FIgURE 9: Fuel reactor enthalpy for CLC of methane.

was observed that some of the oxygen carriers did not get completely converted to the desired reduced state, and hence there was some loss of oxygen carrier material. Table 3 shows the conversion of the oxygen carrier to its lower oxidation states, some of which can be regenerated by acid reaction. However, this loss was found to be negligible, and assuming that the oxygen carriers are very cheap, the CLC process did not seem to suffer any major cost issues on this point.

3.4.2. Enthalpy of the Air Reactor. The reduced oxygen carrier along with solid carbon is continuously circulated back to the air reactor for regeneration. Air is passed through the air reactor, and the reduced oxygen carrier and carbon get 
TABLE 3: Conversion of the oxygen carriers during methane CLC.

\begin{tabular}{|c|c|c|c|c|}
\hline Sr. number & Oxygen carrier & Initial moles & Reduced state & Waste \\
\hline 1 & $\mathrm{CuO}$ & 4 & $\mathrm{Cu}$ (4 moles) $100 \%$ & \\
\hline 2 & $\mathrm{NiO}$ & 4 & $\mathrm{Ni}$ (3.80 mole) 95.05\% & \\
\hline 3 & $\mathrm{CoO}$ & 4 & Co (3.51 mole ) 87.75\% & \\
\hline 4 & $\mathrm{Fe}_{2} \mathrm{O}_{3}$ & 1.33 & $\begin{array}{c}\mathrm{Fe}(1.08 \text { mole }) 40.55 \% \\
\mathrm{FeO}(1.31 \text { mole }) 49.14 \% \\
\mathrm{Fe}_{3} \mathrm{O}_{4}(0.09 \text { mole }) 3.29 \%\end{array}$ & \\
\hline 5 & $\mathrm{Mn}_{2} \mathrm{O}_{3}$ & 1.33 & MnO (2.68 mole) 99.99\% & \\
\hline 6 & $\mathrm{CaSO}_{4}$ & 1 & $\begin{array}{c}\mathrm{CaO}(0.04 \text { mole }) 3.88 \% \\
\mathrm{CaS}(0.93 \text { mole }) 92.55 \% \\
\mathrm{CaCO}_{3}(0.02 \text { mole }) 2.15 \%\end{array}$ & $\begin{array}{c}\mathrm{CaO}(0.04 \text { mole }) 3.88 \% \\
\mathrm{CaCO}_{3}(0.02 \text { mole }) 2.15 \%\end{array}$ \\
\hline 7 & $\mathrm{Na}_{2} \mathrm{SO}_{4}$ & 1 & $\begin{array}{c}\mathrm{Na}_{2} \mathrm{~S}(0.87 \text { mole }) 86.677 \% \\
\mathrm{Na}_{2} \mathrm{CO}_{3}(0.033 \text { mole }) 3.23 \% \\
\mathrm{NaOH}(0.02 \text { mole } 1.69 \%)\end{array}$ & $\mathrm{Na}_{2} \mathrm{CO}_{3}$ (0.033 mole) $3.23 \%$ \\
\hline
\end{tabular}

oxidized completely in the air reactor. This carbon oxidation to $\mathrm{CO}_{2}$ in the air reactor increases the exothermicity of the air reactor as shown below:

$$
\mathrm{C}+\mathrm{O}_{2} \longrightarrow \mathrm{CO}_{2} \quad \Delta \mathrm{H}=-394.75 \mathrm{~kJ}\left(800^{\circ} \mathrm{C}\right)
$$

Figure 10 shows the variation of air reactor enthalpy within the temperature range from 600 to $1200^{\circ} \mathrm{C}$ at 1 bar pressure. It was observed that exothermicity of oxidation increased with increase in air reactor temperature for $\mathrm{Na}_{2} \mathrm{SO}_{4}$; that is, it increased from -268.51 to $-787.29 \mathrm{~kJ}$ for $\mathrm{Na}_{2} \mathrm{SO}_{4}$, while the exothermicity decreased with increase in temperature for $\mathrm{NiO}, \mathrm{CoO}$, and $\mathrm{Mn}_{2} \mathrm{O}_{3}$; it decreased from $-903.24 \mathrm{~kJ}$ to $-852.05 \mathrm{~kJ}$ for $\mathrm{NiO}$, decreased from $-845.94 \mathrm{~kJ}$ to $-762.33 \mathrm{~kJ}$ for $\mathrm{CoO}$, and decreased from $-513.18 \mathrm{~kJ}$ to $-240.21 \mathrm{~kJ}$ for $\mathrm{Mn}_{2} \mathrm{O}_{3}$ with increase in air reactor temperature from 600 to $1200^{\circ} \mathrm{C}$. A different trend was observed for $\mathrm{CaSO}_{4}$, where the exothermicity of oxidation first increased and then decreased with increase in temperature; that is, it increased from $-794.68 \mathrm{~kJ}\left(600^{\circ} \mathrm{C}\right)$ to $-877.44 \mathrm{~kJ}\left(800^{\circ} \mathrm{C}\right)$ and then decreased to $-784.08 \mathrm{~kJ}\left(1200^{\circ} \mathrm{C}\right)$, while mixed trend was observed for $\mathrm{CuO}$. An enthalpy decrease-increase-decrease trend was observed for $\mathrm{Fe}_{2} \mathrm{O}_{3}$ as seen in the figure. The selectivity of oxygen carriers according to the maximum exothermicity of the reaction is as follows: $\mathrm{NiO}(-903.24 \mathrm{~kJ}$, $\left.600^{\circ} \mathrm{C}\right)>\mathrm{CaSO}_{4}\left(-877.44 \mathrm{~kJ}, 800^{\circ} \mathrm{C}\right)>\mathrm{CoO}(-845.94 \mathrm{~kJ}$, $\left.600^{\circ} \mathrm{C}\right)>\mathrm{Na}_{2} \mathrm{SO}_{4}\left(-787.29 \mathrm{~kJ}, 1200^{\circ} \mathrm{C}\right)>\mathrm{CuO}(-640.17 \mathrm{~kJ}$, $\left.1100^{\circ} \mathrm{C}\right)>\mathrm{Fe}_{2} \mathrm{O}_{3}\left(-629.23 \mathrm{~kJ}, 1200^{\circ} \mathrm{C}\right)>\mathrm{Mn}_{2} \mathrm{O}_{3}(-513.18 \mathrm{~kJ}$, $\left.600^{\circ} \mathrm{C}\right)$.

3.4.3. Net Process Heat. The net energy required for the CLC process was calculated by summing up the energies of the exothermic air reactor and endothermic fuel reactor for identical oxygen carrier and carbon processing for 1 mole methane feed. The energy generated due to the exothermic air reactor is utilized for reduction of the oxygen carrier in the fuel reactor. The carbon formed in the fuel reactor and its oxidation to $\mathrm{CO}_{2}$ in the air reactor provided additional energy.

Figure 11 shows that net process heat was obtained by using different oxygen carriers within the temperature range

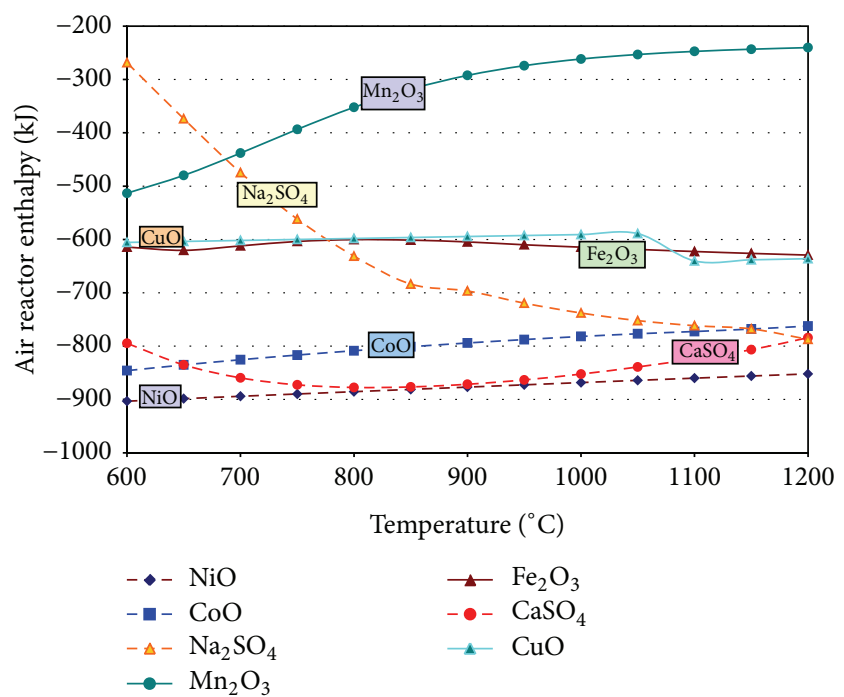

FIGURE 10: Air reactor enthalpy for CLC of methane.

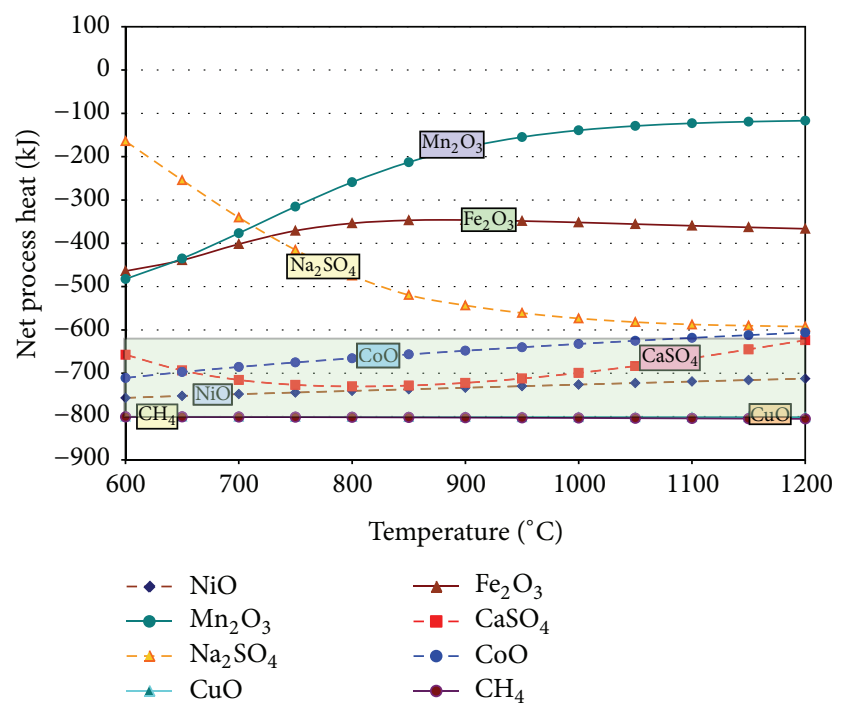

Figure 11: Net process heat for CLC of methane. 
from 600 to $1200^{\circ} \mathrm{C}$ at 1 bar pressure. It was observed that the net process exothermicity decreased with increase in temperature for $\mathrm{NiO}, \mathrm{Mn}_{2} \mathrm{O}_{3}$, and $\mathrm{CoO}$; that is, it decreased from $-756.91 \mathrm{~kJ}$ to $-712.44 \mathrm{~kJ}$ for $\mathrm{NiO}$, decreased from $-482.52 \mathrm{~kJ}$ to $-116.99 \mathrm{~kJ}$ for $\mathrm{Mn}_{2} \mathrm{O}_{3}$, and decreased from $-710.79 \mathrm{~kJ}$ to $-606.11 \mathrm{~kJ}$ for $\mathrm{CoO}$, while net process heat increased with increase in temperature for $\mathrm{Na}_{2} \mathrm{SO}_{4}$; that is, it increased from $-164.35 \mathrm{~kJ}$ to $-592.38 \mathrm{~kJ}$ for $\mathrm{Na}_{2} \mathrm{SO}_{4}$. The net exothermicity first increased and then decreased with increase in temperature; that is, it increased from $-657.26 \mathrm{~kJ}\left(600^{\circ} \mathrm{C}\right)$ to $-730.48 \mathrm{~kJ}\left(800^{\circ} \mathrm{C}\right)$ and then decreased to $-623.75 \mathrm{~kJ}\left(1200^{\circ} \mathrm{C}\right)$ for $\mathrm{CaSO}_{4}$, while the exothermicity first decreased and then increased with increase in temperature for $\mathrm{Fe}_{2} \mathrm{O}_{3}$; that is, it decreased from $-464.15 \mathrm{~kJ}\left(600^{\circ} \mathrm{C}\right)$ to $-346.2 \mathrm{~kJ}\left(900^{\circ} \mathrm{C}\right)$ and then increased to $-366.46 \mathrm{~kJ}\left(1200^{\circ} \mathrm{C}\right)$. It was observed that the net process exothermicity remained almost constant for $\mathrm{CuO}$. The oxygen carriers were ranked according to the increase in the net process exothermicity $(\mathrm{kJ})$, and the trend was observed as follows: $\mathrm{CuO}\left(-801.68 \mathrm{~kJ}, 1150^{\circ} \mathrm{C}\right)$ $>\mathrm{NiO}\left(-756.91 \mathrm{~kJ}, 600^{\circ} \mathrm{C}\right)>\mathrm{CaSO}_{4}\left(-730.48 \mathrm{~kJ}, 800^{\circ} \mathrm{C}\right)>$ $\mathrm{CoO}\left(-710.79 \mathrm{~kJ}, 600^{\circ} \mathrm{C}\right)>\mathrm{Na}_{2} \mathrm{SO}_{4}\left(-592.38 \mathrm{~kJ}, 1200^{\circ} \mathrm{C}\right)>$ $\mathrm{Mn}_{2} \mathrm{O}_{3}\left(-482.52 \mathrm{~kJ}, 600^{\circ} \mathrm{C}\right)>\mathrm{Fe}_{2} \mathrm{O}_{3}\left(-464.15 \mathrm{~kJ}, 600^{\circ} \mathrm{C}\right)$. These values were compared with the value of energy of methane combustion. It was observed that the CLC did not exactly give the complete energy that can be obtained from 1 mole methane by air oxidation. This is due to the byproduct formation in the fuel reactor. Although carbon formed in the CLC fuel reactor is oxidized in the air reactor, the syngas and unconverted methane escape in the CLC fuel reactor product stream mainly causing the loss in fuel and subsequent energy. This loss can be reduced by adding excess of oxygen carrier in the fuel reactor. However, this large additional amount of oxygen carrier for small conversion in the fuel reactor thereby increases the process operating cost. Hence, adding a secondary fuel reactor using some more oxygen carriers to oxidise the $\mathrm{H}_{2}$, $\mathrm{CO}$, and $\mathrm{CH}_{4}$ completely in the second stage seems to be a better option.

3.5. Weight of Oxygen Carrier. The CLC system involves circulation of the hot oxygen carrier from the air reactor to fuel reactor for reduction. The reduced oxygen carrier is then sent back to the air reactor for oxidation. This continuous recirculation of the solid oxygen carrier requires considerable energy. Hence, an estimate of weight of the oxygen carrier is important for the process engineer to help choose the right oxygen carrier. Table 4 shows the oxygen carrier requirement per mole methane used in the CLC process. It was observed that 4 moles of $\mathrm{CuO}, \mathrm{NiO}$, and $\mathrm{CoO}$ were required per mole methane used in the CLC process; hence, their weight is much higher than the sulfate oxygen carriers. The $\mathrm{CuO}, \mathrm{NiO}$, and $\mathrm{CoO}$ oxygen carriers were the heaviest, followed by $\mathrm{Fe}_{2} \mathrm{O}_{3}$ and $\mathrm{Mn}_{2} \mathrm{O}_{3}$. The $\mathrm{Ca}$ and $\mathrm{Na}$ sulfates were found to have lowest weight for use in this study. The favorable oxygen carrier was the lowest amount of the required oxygen carrier (in weight), and the ranking based on this criterion was found to be $\mathrm{CaSO}_{4}>\mathrm{Na}_{2} \mathrm{SO}_{4}>\mathrm{Mn}_{2} \mathrm{O}_{3}>\mathrm{Fe}_{2} \mathrm{O}_{3}>\mathrm{NiO}>\mathrm{CoO}$ $>\mathrm{CuO}$. However, the trend of net energy obtainable with stoichiometric amount of oxygen carrier was found to be

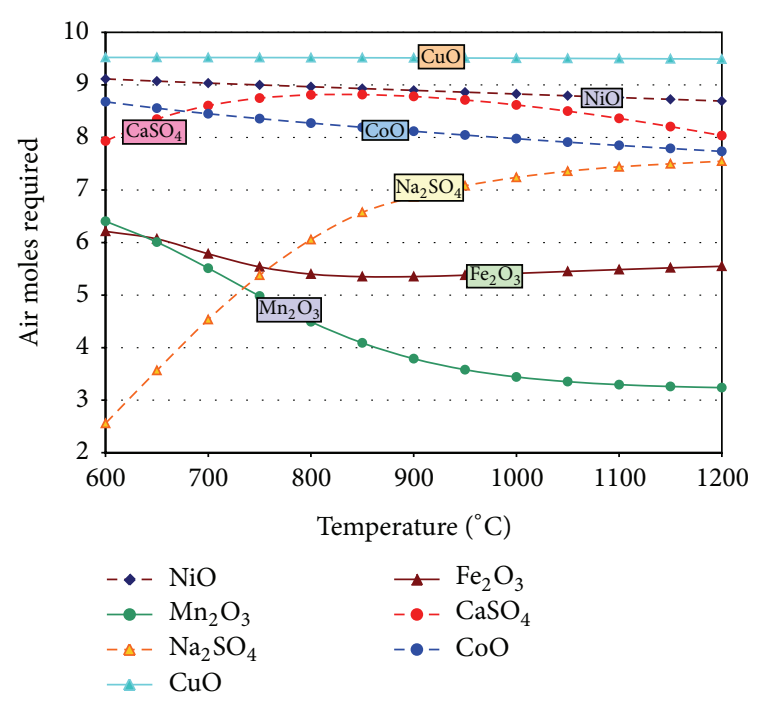

FIGURE 12: Air moles required for CLC of methane.

different. Hence, this criterion was compared on the basis of maximum net energy obtained per gram of the oxygen carrier (Table 4 ) and the ranking based on this criterion was observed to follow the sequence: $\mathrm{CaSO}_{4}\left(-5.3657 \mathrm{~kJ}, 800^{\circ} \mathrm{C}\right)$ $>\mathrm{Na}_{2} \mathrm{SO}_{4}\left(-4.1705 \mathrm{~kJ}, 1200^{\circ} \mathrm{C}\right)>\mathrm{NiO}\left(-2.5334 \mathrm{~kJ}, 600^{\circ} \mathrm{C}\right)$ $>\mathrm{CuO}\left(-2.5196 \mathrm{~kJ}, 1150^{\circ} \mathrm{C}\right)>\mathrm{CoO}\left(-2.3714 \mathrm{~kJ}, 600^{\circ} \mathrm{C}\right)>$ $\mathrm{Mn}_{2} \mathrm{O}_{3}\left(-2.2981 \mathrm{~kJ}, 600^{\circ} \mathrm{C}\right)>\mathrm{Fe}_{2} \mathrm{O}_{3}\left(-2.1855 \mathrm{~kJ}, 600^{\circ} \mathrm{C}\right)$.

3.6. Air Requirement. The CLC of methane can be accomplished by using a variety of oxygen carriers. The reduction of oxygen carriers is different to different potentials depending on CLC conditions. The regeneration of the reduced oxygen carrier as well as carbon oxidation reaction requires air for regeneration. The (stiochometric) requirement of air moles in the air reactor per mole of methane used in CLC was calculated to understand the operating costs related to air input. Figure 12 shows the total air moles required for different oxygen carriers in CLC of methane process in the temperature range from $600^{\circ} \mathrm{C}$ to $1200^{\circ} \mathrm{C}$. The oxygen carrier and carbon were oxidised by air in the air reactor. It was observed that total moles of air used decreased with increase in temperature for $\mathrm{NiO}, \mathrm{Mn}_{2} \mathrm{O}_{3}$, and $\mathrm{CoO}$; it decreased from 9.11 to 8.69 moles for $\mathrm{NiO}$, decreased from 6.40 to 3.24 moles for $\mathrm{Mn}_{2} \mathrm{O}_{3}$, and decreased from 8.68 to 7.73 moles for $\mathrm{CoO}$, while the total air moles used remained almost constant at 9.50 moles for $\mathrm{CuO}$ and it increased with increase in temperature for $\mathrm{Na}_{2} \mathrm{SO}_{4}$, that is, from 2.56 to 7.55 moles for $\mathrm{Na}_{2} \mathrm{SO}_{4}$, while for $\mathrm{Fe}_{2} \mathrm{O}_{3}$, it first decreased from $6.21\left(600^{\circ} \mathrm{C}\right)$ to 5.35 moles $\left(850^{\circ} \mathrm{C}\right)$ and then increased to 5.55 moles $\left(1200^{\circ} \mathrm{C}\right)$. The total air moles used first increased till $850^{\circ} \mathrm{C}$ and then slightly decreased with increase in temperature for $\mathrm{CaSO}_{4}$; that is, it increased from 7.93 to 8.81 moles and then slightly decreased to 8.04 moles. Selectivity of the oxygen carriers according to the lowest amount of air moles used in the process was as follows: $\mathrm{Na}_{2} \mathrm{SO}_{4}$ (2.56 moles, $\left.600^{\circ} \mathrm{C}\right)>\mathrm{Mn}_{2} \mathrm{O}_{3}\left(3.24\right.$ moles, $\left.1200^{\circ} \mathrm{C}\right)>\mathrm{Fe}_{2} \mathrm{O}_{3}$ (5.35 moles, $\left.850^{\circ} \mathrm{C}\right)>\mathrm{CoO}\left(7.73\right.$ moles, $\left.1200^{\circ} \mathrm{C}\right)>\mathrm{CaSO}_{4}$ (7.93 moles, 
TABLE 4: Weight of oxygen carriers.

\begin{tabular}{lcccc}
\hline Oxygen carrier & $\begin{array}{c}\text { Molecular wt. of oxygen } \\
\text { carrier (for 1 mole) }\end{array}$ & $\begin{array}{c}\text { Moles of oxygen } \\
\text { carrier }\end{array}$ & $\begin{array}{c}\text { Oxygen carrier } \\
\text { weight (gram) }\end{array}$ & $\begin{array}{c}\text { (max) Net process heat (kJ/gram) } \\
\text { of oxygen carrier }\end{array}$ \\
\hline $\mathrm{CuO}$ & 79.55 & 4 & 318.18 & -2.5196 \\
$\mathrm{NiO}$ & 74.7 & 4 & 298.77 & -2.5334 \\
$\mathrm{CoO}$ & 74.93 & 4 & 299.73 & -2.3714 \\
$\mathrm{Fe}_{2} \mathrm{O}_{3}$ & 159.69 & 1.33 & 212.38 & -2.1855 \\
$\mathrm{Mn}_{2} \mathrm{O}_{3}$ & 157.87 & 1.33 & 209.97 & -2.2981 \\
$\mathrm{CaSO}_{4}$ & 136.14 & 1 & 136.14 & -5.3657 \\
$\mathrm{Na}_{2} \mathrm{SO}_{4}$ & 142.04 & 1 & 142.04 & -4.1705 \\
\hline
\end{tabular}

TABLE 5: Variation of $\mathrm{CO}_{2}$ moles with increase in stoichiometric amount (S) of NiO.

(a)

\begin{tabular}{lccc}
\hline$(\mathrm{S}=$ stoichiometric amount of $\mathrm{NiO})$ & $1 \mathrm{~S}$ & $2 \mathrm{~S}$ & $3 \mathrm{~S}$ \\
\hline Weight $($ grams $)$ of oxygen carrier $(\mathrm{NiO})$ & 318.2 & 636.4 & 954.6 \\
\hline
\end{tabular}

(b)

\begin{tabular}{lccccc}
\hline Temperature $\left({ }^{\circ} \mathrm{C}\right)$ & $(1 \mathrm{~S})$ & $\begin{array}{c}\mathrm{CO}_{2} \text { moles } \\
(2 \mathrm{~S})\end{array}$ & $(3 \mathrm{~S})$ & \% increase (1S-2S) & \% increase (1S-3S) \\
\hline 600 & 0.9588 & 0.9984 & 0.9992 & 4.1335 & 4.2159 \\
750 & 0.9353 & 0.9960 & 0.9980 & 6.4931 & 6.7037 \\
1000 & 0.8696 & 0.9884 & 0.9941 & 13.6714 & 14.3269 \\
1200 & 0.8151 & 0.9791 & 0.9893 & 20.1251 & 21.3765 \\
\hline
\end{tabular}

$\left.600^{\circ} \mathrm{C}\right)>\mathrm{NiO}\left(8.69\right.$ moles, $\left.1200^{\circ} \mathrm{C}\right)>\mathrm{CuO}(9.49$ moles, $\left.1200^{\circ} \mathrm{C}\right)$.

\subsection{Effect of Pressure and Amount of Oxygen Carrier on} Methane CLC Process. Pressure is an important process parameter. According to Le Chatelier's principle, the effect of increase in process pressure on the reaction in the CLC fuel reactor seems negative; that is, the $\mathrm{H}_{2} \mathrm{O}$ and $\mathrm{CO}_{2}$ yield decreased with increase in pressure at constant temperature for all oxygen carriers. The amount of oxygen carrier in the CLC system is based on the stoichiometric reaction. However, formation of syngas is seen due to thermodynamic limitations. An increase in the amount of oxygen carrier (greater than the stoichiometric amount) can enhance the conversion of fuel selectively to $\mathrm{CO}_{2}$ and $\mathrm{H}_{2} \mathrm{O}$. However, this increase in the oxygen carrier quantity can put load on the solid conveying system of CLC. Table 5 shows the increase in the $\mathrm{CO}_{2}$ yield by using different amounts ( $\mathrm{S}-$ stoichiometric amount, $2 \mathrm{~S}$ and $3 \mathrm{~S}$ ) of the oxygen carrier $(\mathrm{NiO})$ at different temperatures. It can be seen that increase in the amount of oxygen carrier increases the solid input to the system in a huge quantity, but the $\mathrm{CO}_{2}$ yield increases only meagrely. Hence, stoichiometric amount of the oxygen carrier is the optimum quantity to be used in the CLC system.

3.8. Discussion. Properties of oxygen carrier significantly affect the overall performance of CLC process. The oxygen carriers selected for this study have been reported by researchers as potential oxygen carriers under experimental reaction and regeneration trials. The results obtained in this study inferred valuable information for selection of oxygen carrier for methane CLC. Table 6 shows the preferable oxygen carriers for the different criteria. From Table 6, it is observed that $\mathrm{CuO}$ and $\mathrm{NiO}$ showed better results among the oxidebased oxygen carriers. $\mathrm{CuO}$ and $\mathrm{NiO}$ have good desired product yield with negligible undesired product formation. Net process heat per gram of oxygen carrier is found to be maximum for $\mathrm{NiO}$, followed by $\mathrm{CuO}$. Among the sulphatebased oxygen carriers, $\mathrm{CaSO}_{4}$ showed better results under most of the conditions considered. CLC operation involves the fluidization of oxygen carrier particles, and the energy required for solid oxygen carrier transport is a critical parameter for process operation. Hence, it is desirable to obtain maximum energy in CLC using lowest weight (amount) of oxygen carrier. Although the performance of oxygen carriers like $\mathrm{NiO}$ and $\mathrm{CaSO}_{4}$ is similar, $\mathrm{CaSO}_{4}$ produces higher net process heat in methane CLC per gram of oxygen carrier used in the process.

\section{Conclusion}

A theoretical study of CLC of methane process was done for some important criteria related to technology development using different low-cost, easily available inorganic solids as oxygen carriers and some interesting results were obtained. While oxygen carrier plays very crucial role in technoeconomic feasibility of CLC process, the choice of the oxygen 
TABLE 6: Ranking of oxygen carrier.

\begin{tabular}{|c|c|c|}
\hline $\begin{array}{l}\text { Sr. } \\
\text { number }\end{array}$ & Criteria for section of oxygen carrier & Ranking of oxygen carrier \\
\hline 1 & $\mathrm{H}_{2} \mathrm{O}$ yield (moles) & $\mathrm{CuO}>\mathrm{CaSO}_{4}>\mathrm{NiO}>\mathrm{CoO}>\mathrm{Na}_{2} \mathrm{SO}_{4}>\mathrm{Fe}_{2} \mathrm{O}_{3}>\mathrm{Mn}_{2} \mathrm{O}_{3}$ \\
\hline 2 & $\mathrm{CO}_{2}$ yield (moles) & $\mathrm{CuO}>\mathrm{NiO}>\mathrm{CaSO}_{4}>\mathrm{CoO}>\mathrm{Na}_{2} \mathrm{SO}_{4}>\mathrm{Fe}_{2} \mathrm{O}_{3}>\mathrm{Mn}_{2} \mathrm{O}_{3}$ \\
\hline 3 & $\mathrm{H}_{2} \mathrm{O}+\mathrm{CO}_{2}$ yield (moles) & $\mathrm{CuO}>\mathrm{CaSO}_{4}>\mathrm{NiO}>\mathrm{CoO}>\mathrm{Na}_{2} \mathrm{SO}_{4}>\mathrm{Fe}_{2} \mathrm{O}_{3}>\mathrm{Mn}_{2} \mathrm{O}_{3}$ \\
\hline 4 & Carbon formation (moles) & $\mathrm{Mn}_{2} \mathrm{O}_{3}<\mathrm{Fe}_{2} \mathrm{O}_{3}<\mathrm{CoO}<\mathrm{NiO}<\mathrm{Na}_{2} \mathrm{SO}_{4}<\mathrm{CaSO}_{4}<\mathrm{CuO}$ \\
\hline 5 & Syngas yield (moles) & $\mathrm{CuO}>\mathrm{CaSO}_{4}>\mathrm{Na}_{2} \mathrm{SO}_{4}>\mathrm{NiO}>\mathrm{CoO}>\mathrm{Mn}_{2} \mathrm{O}_{3}>\mathrm{Fe}_{2} \mathrm{O}_{3}$ \\
\hline 6 & Net process heat $(\mathrm{kJ})$ & $\mathrm{CuO}>\mathrm{NiO}>\mathrm{CaSO}_{4}>\mathrm{CoO}>\mathrm{Na}_{2} \mathrm{SO}_{4}>\mathrm{Mn}_{2} \mathrm{O}_{3}>\mathrm{Fe}_{2} \mathrm{O}_{3}$ \\
\hline 7 & Oxygen carriers used (gram) & $\mathrm{CaSO}_{4}>\mathrm{Na}_{2} \mathrm{SO}_{4}>\mathrm{Mn}_{2} \mathrm{O}_{3}>\mathrm{Fe}_{2} \mathrm{O}_{3}>\mathrm{NiO}>\mathrm{CoO}>\mathrm{CuO}$ \\
\hline 8 & $\begin{array}{l}\text { Air moles required in CLC process of } \\
\text { methane (moles) }\end{array}$ & $\mathrm{Na}_{2} \mathrm{SO}_{4}>\mathrm{Mn}_{2} \mathrm{O}_{3}>\mathrm{Fe}_{2} \mathrm{O}_{3}>\mathrm{CoO}>\mathrm{CaSO}_{4}>\mathrm{NiO}>\mathrm{CuO}$ \\
\hline 9 & $\begin{array}{l}\text { Net process heat/gram of oxygen } \\
\text { carriers }(\mathrm{kJ} / \mathrm{g})\end{array}$ & $\begin{array}{l}\mathrm{CaSO}_{4}\left(-5.3657 \mathrm{~kJ}, 800^{\circ} \mathrm{C}\right)>\mathrm{Na}_{2} \mathrm{SO}_{4}\left(-4.1705 \mathrm{~kJ}, 1200^{\circ} \mathrm{C}\right)>\mathrm{NiO}(-2.5334 \mathrm{~kJ}, \\
\left.600^{\circ} \mathrm{C}\right)>\mathrm{CuO}\left(-2.5196 \mathrm{~kJ}, 1150^{\circ} \mathrm{C}\right)>\mathrm{CoO}\left(-2.3714 \mathrm{~kJ}, 600^{\circ} \mathrm{C}\right)>\mathrm{Mn}_{2} \mathrm{O}_{3} \\
\left(-2.2929 \mathrm{~kJ}, 600^{\circ} \mathrm{C}\right)>\mathrm{Fe}_{2} \mathrm{O}_{3}\left(-2.1805 \mathrm{~kJ}, 600^{\circ} \mathrm{C}\right)\end{array}$ \\
\hline
\end{tabular}

carrier in CLC for a particular fuel is affected by several factors. The combined desired product yield $\left(\mathrm{H}_{2} \mathrm{O}+\mathrm{CO}_{2}\right)$ is a better criterion than individual products yield to obtain optimum condition in CLC. Carbon formation in the fuel reactor eventually forms $\mathrm{CO}_{2}$ in the air reactor, and hence the oxygen carrier/process condition resulting in negligible carbon formation in fuel reactor must be chosen. The CLC process should be operated at the desired condition to get maximum net obtainable energy. The oxygen carrier can result in several reduced species. The oxygen carrier that delivers the maximum net energy per unit weight in the CLC process should be preferred for the reasons discussed. The oxygen carrier requiring lowest continuous air input in the air reactor is also preferable. Oxides such as $\mathrm{Fe}_{2} \mathrm{O}_{3}$ and $\mathrm{Mn}_{2} \mathrm{O}_{3}$ showed multiple reduced states, while $\mathrm{CuO}, \mathrm{CoO}$, and $\mathrm{NiO}$ had only one reduced state. $\mathrm{H}_{2} \mathrm{~S}, \mathrm{SO}_{2}$, oxide, and carbonate formation were observed in sulfates as oxygen carriers; however, in this case, the operating weight of oxygen carrier as well as operating air requirement was less as compared to the oxide-based oxygen carriers. The combined desired product yield $\left(\mathrm{CO}_{2}+\mathrm{H}_{2} \mathrm{O}\right)$ was maximum for $\mathrm{CuO}$ and $\mathrm{CaSO}_{4}$. It was observed that $\mathrm{CuO}$ resulted in zero carbon formation over the operating temperature range, while $\mathrm{CaSO}_{4}$ had almost negligible carbon formation. The net energy obtained per gram of the oxygen carrier and $\mathrm{CH}_{4}$ conversion was found to be maximum for $\mathrm{CaSO}_{4}$. The reduced species of $\mathrm{CaSO}_{4}$ like $\mathrm{CaS}$ can be regenerated by air oxidation, while $\mathrm{CaO}$ can be reacted with dil. $\mathrm{H}_{2} \mathrm{SO}_{4}$ to form $\mathrm{CaSO}_{4}$. Use of $\mathrm{CaSO}_{4}$ results in slight formation of $\mathrm{H}_{2} \mathrm{~S}$ and $\mathrm{SO}_{2}$. The formation of syngas is found to be negligible for $\mathrm{CaSO}_{4}$. Even though $\mathrm{CuO}$ shows better results for few cases, $\mathrm{CaSO}_{4}$ is more preferable because of the limitation of the operating temperature range for $\mathrm{CuO}$ as it could not be reoxidized to its original state due to sintering, which has been studied by some researchers [82, 83]. This also explained some discrepancy in graphs observed for $\mathrm{CuO}$ at higher temperatures. Overall, considering the complexity of CLC operations with large number of variables as well as significantly different behaviours of various oxygen carriers at different temperatures, it is essential to understand their thermodynamic properties and theoretical estimations of various parameters. These findings can also be extended to other similar materials and fuels for CLC.

\section{References}

[1] B. M. Corbella, L. D. Diego, F. Garc1, J. Adánez, and J. M. Palacios, "The performance in a fixed bed reactor of copperbased oxides on titania as oxygen carriers for chemical looping combustion of methane," Energy Fuels, vol. 19, no. 2, pp. 433441, 2005.

[2] M. Anheden and G. Svedberg, "Chemical-looping combustion in combination with integrated coal gasification-a way to avoid $\mathrm{CO}_{2}$ emission from coal fired power plants without a significant decrease in net power efficiency," in Proceedings of the 31st Intersociety Energy Conversion Engineering Conference, pp. 2045-2050, August 1996.

[3] B. R. Parizek and R. B. Alley, "Implications of increased Greenland surface melt under global-warming scenarios: icesheet simulations," Quaternary Science Reviews, vol. 23, pp. 1013-1027, 2004.

[4] M. Hishida, M. Fumizawa, Y. Inaba et al., "Nuclear energy conversion systems for arresting global warming," Energy Conversion and Management, vol. 38, no. 10-13, pp. 1365-1375, 1997.

[5] L. Sun and M. Wang, "Global warming and global dioxide emission: an empirical study," Journal of Environmental Management, vol. 46, no. 4, pp. 327-343, 1996.

[6] Wmo greenhouse gas bulletin. World Meterological Organization. No 7, November 2011.

[7] T. Mattisson, A. Lyngfelt, and P. Cho, "The use of iron oxide as an oxygen carrier in chemical-looping combustion of methane with inherent separation of $\mathrm{CO}_{2}$," Fuel, vol. 80, no. 13, pp. 19531962, 2001.

[8] J. Jung and I. K. Gamwo, "Multiphase CFD-based models for chemical looping combustion process: fuel reactor modeling," Powder Technology, vol. 183, no. 3, pp. 401-409, 2008.

[9] A. Abad, T. Mattisson, A. Lyngfelt, and M. Rydén, "Chemicallooping combustion in a $300 \mathrm{~W}$ continuously operating reactor system using a manganese-based oxygen carrier," Fuel, vol. 85, no. 9, pp. 1174-1185, 2006.

[10] H. Jin and M. Ishida, "A new type of coal gas fueled chemicallooping combustion," Fuel, vol. 83, no. 17-18, pp. 2411-2417, 2004. 
[11] A. Lyngfelt, B. Leckner, and T. Mattisson, "A fluidized-bed combustion process with inherent $\mathrm{CO}_{2}$ separation; application of chemical-looping combustion," Chemical Engineering Science, vol. 56, no. 10, pp. 3101-3113, 2001.

[12] J. S. Dennis, C. R. Müller, and A. Stuart, "In situ gasification and $\mathrm{CO}_{2}$ separation using chemical looping with a $\mathrm{Cu}$-based oxygen carrier: performance with bituminous coals," Fuel, vol. 89, pp. 2353-2364, 2010.

[13] M. Keller, H. Leion, T. Mattisson, and A. Lyngfelt, "Gasification inhibition in chemical-looping combustion with solid fuels," Combustion and Flame, vol. 158, no. 3, pp. 393-400, 2011.

[14] H. Wakita, Y. Sano, A. Urabe, and Y. Nakamura, "Origin of methane-rich natural gas in Japan: formation of gas fields due to large-scale submarine volcanism," Applied Geochemistry, vol. 5, no. 3, pp. 263-278, 1990.

[15] A. L. Dicks, J. C. D. da Costa, A. Simpson, and B. McLellan, "Fuel cells, hydrogen and energy supply in Australia," Journal of Power Sources, vol. 131, no. 1-2, pp. 1-12, 2004.

[16] A. L. Dicks, "Hydrogen generation from natural gas for the fuel cell systems of tomorrow," Journal of Power Sources, vol. 61, no. 1-2, pp. 113-124, 1996.

[17] B. C. H. Steele, "Running on natural gas," Nature, vol. 400, no. 6745, pp. 619-621, 1999.

[18] C. Linderholm, T. Mattisson, and A. Lyngfelt, "Long-term integrity testing of spray-dried particles in a $10-\mathrm{kW}$ chemicallooping combustor using natural gas as fuel," Fuel, vol. 88, no. 11, pp. 2083-2096, 2009.

[19] H. Jin and M. Ishida, "Reactivity study on natural-gas-fueled chemical-looping combustion by a fixed-bed reactor," Industrial \& Engineering Chemistry Research, vol. 41, pp. 4004-4007, 2002.

[20] P. Kolbitsch, T. Proll, and H. Hofbauer, "Modeling of a $120 \mathrm{~kW}$ chemical looping combustion reactor system using a Ni-based oxygen carrier," Chemical Engineering Science, vol. 64, pp. 99108, 2009.

[21] A. Dicks, T. Connor, J. Bradley, and A. Lashtabeg, "Impact of Australian natural gas and coal bed methane composition on PEM fuel cell performance," International Journal of Hydrogen Energy, vol. 34, no. 21, pp. 8892-8904, 2009.

[22] E. Porpatham, A. Ramesh, and B. Nagalingam, "Investigation on the effect of concentration of methane in biogas when used as a fuel for a spark ignition engine," Fuel, vol. 87, no. 8-9, pp. 1651-1659, 2008.

[23] S. K. Sharma, J. S. Saini, I. M. Mishra, and M. P. Sharma, "Mirabilis leaves-a potential source of methane," Biomass, vol. 13, no. 1, pp. 13-24, 1987.

[24] S. K. Sharma, I. M. Mishra, M. P. Sharma, and J. S. Saini, "Effect of particle size on biogas generation from biomass residues," Biomass, vol. 17, no. 4, pp. 251-263, 1988.

[25] J. Huang and R. J. Crookes, "Assessment of simulated biogas as a fuel for the spark ignition engine," Fuel, vol. 77, no. 15, pp. 1793$1801,1998$.

[26] P. Lunghi, R. Bove, and U. Desideri, "Life-cycle-assessment of fuel-cells-based landfill-gas energy conversion technologies," Journal of Power Sources, vol. 131, no. 1-2, pp. 120-126, 2004.

[27] R. Bove and P. Lunghi, "Electric power generation from landfill gas using traditional and innovative technologies," Energy Conversion and Management, vol. 47, no. 11-12, pp. 1391-1401, 2006.

[28] R. J. Spiegel, J. L. Preston, and J. C. Trocciola, "Fuel cell operation on landfill gas at Penrose Power Station," Energy, vol. 24, no. 8, pp. 723-742, 1999.
[29] R. J. Spiegel and J. L. Preston, "Technical assessment of fuel cell operation on landfill gas at the Groton, CT, landfill," Energy, vol. 28, no. 5, pp. 397-409, 2003.

[30] R. J. Spiegel, J. C. Trocciola, and J. L. Preston, “Test results for fuel-cell operation on landfill gas," Energy, vol. 22, no. 8, pp. 777786, 1997.

[31] W. T. Tsai, "Bioenergy from landfill gas (LFG) in Taiwan," Renewable and Sustainable Energy Reviews, vol. 11, no. 2, pp. 331344, 2007.

[32] K. A. Kvenvolden, "A review of the geochemistry of methane in natural gas hydrate," Organic Geochemistry, vol. 23, no. 11-12, pp. 997-1008, 1995.

[33] S.-Y. Lee and G. D. Holder, "Methane hydrates potential as a future energy source," Fuel Processing Technology, vol. 71, no. 13, pp. 181-186, 2001.

[34] E. Desa, "Submarine methane hydrates-potential fuel resource of the 21st century," Proceedings of Andra Pradesh Akademi of Sciences, vol. 5, no. 2, pp. 101-114, 2001.

[35] W. Rice, "Hydrogen production from methane hydrate with sequestering of carbon dioxide," International Journal of Hydrogen Energy, vol. 31, no. 14, pp. 1955-1963, 2006.

[36] W. D. Gunter, T. Gentzis, B. A. Rottenfusser, and R. J. H. Richardson, "Deep coalbed methane in Alberta, Canada: a fuel resource with the potential of zero greenhouse gas emissions," Energy Conversion and Management, vol. 38, no. 1, pp. S217S222, 1997.

[37] J. J. Lay, Y. Y. Li, T. Noike, J. Endo, and S. Ishimoto, "Analysis of environmental factors affecting methane production from high-solids organic waste," Water Science and Technology, vol. 36, no. 6-7, pp. 493-500, 1997.

[38] D. P. Chynoweth, J. M. Owens, and R. Legrand, "Renewable methane from anaerobic digestion of biomass," Renewable Energy, vol. 22, no. 1-3, pp. 1-8, 2001.

[39] Y. Li, S. Y. Park, and J. Zhu, "Solid-state anaerobic digestion for methane production from organic waste," Renewable and Sustainable Energy Reviews, vol. 15, no. 1, pp. 821-826, 2011.

[40] M. Hammad, D. Badarneh, and K. Tahboub, "Evaluating variable organic waste to produce methane," Energy Conversion and Management, vol. 40, no. 13, pp. 1463-1475, 1999.

[41] G. J. MacDonald, “The future of methane as an energy resource," Annual Review of Energy, vol. 15, pp. 53-83, 1990.

[42] T. Mattisson, M. Johansson, and A. Lyngfelt, "The use of $\mathrm{NiO}$ as an oxygen carrier in chemical-looping combustion," Fuel, vol. 85, no. 5-6, pp. 736-747, 2006.

[43] L. Shen, M. Zheng, J. Xiao, and R. Xiao, "A mechanistic investigation of a calcium-based oxygen carrier for chemical looping combustion," Combustion and Flame, vol. 154, no. 3, pp. 489-506, 2008.

[44] T. Mattisson and A. Lyngfelt, "Capture of $\mathrm{CO}_{2}$ using chemicallooping combustion," in Proceedings of the 1st Biennial Meeting of the Scandinavian-Nordic Section of the Combustion Institute, Göteborg, Sweden, April 2001.

[45] T. Mattisson, E. Jerndal, C. Linderholm, and A. Lyngfelt, "Reactivity of a spray-dried $\mathrm{NiO} / \mathrm{NiAl}_{2} \mathrm{O}_{4}$ oxygen carrier for chemical-looping combustion," Chemical Engineering Science, vol. 66, no. 20, pp. 4636-4644, 2011.

[46] B. M. Corbella and J. M. Palacios, "Titania-supported iron oxide as oxygen carrier for chemical-looping combustion of methane," Fuel, vol. 86, no. 1-2, pp. 113-122, 2007.

[47] M. Johansson, T. Mattisson, and A. Lyngfelt, "Investigation of $\mathrm{Mn}_{3} \mathrm{O}_{4}$ with stabilized $\mathrm{ZrO} 2$ for chemical-looping combustion," 
Chemical Engineering Research and Design, vol. 84, no. 9, pp. 807-818, 2006.

[48] M. Rydén, E. Cleverstam, A. Lyngfelt, and T. Mattisson, "Waste products from the steel industry with $\mathrm{NiO}$ as additive as oxygen carrier for chemical-looping combustion," International Journal of Greenhouse Gas Control, vol. 3, no. 6, pp. 693-703, 2009.

[49] C. R. Forero, P. Gayán, F. García-Labiano, L. F. de Diego, A. Abad, and J. Adánez, "Effect of gas composition in ChemicalLooping Combustion with copper-based oxygen carriers: fate of sulphur," International Journal of Greenhouse Gas Control, vol. 4, no. 5, pp. 762-770, 2010.

[50] R. Kuusik, A. Trikkel, A. Lyngfelt, and T. Mattisson, "High temperature behavior of $\mathrm{NiO}$-based oxygen carriers for chemical looping combustion," Energy Procedia, vol. 1, pp. 3885-3892, 2009.

[51] Q. Zafar, A. Abad, T. Mattisson, B. Gevert, and M. Strand, "Reduction and oxidation kinetics of $\mathrm{Mn}_{3} \mathrm{O}_{4} / \mathrm{Mg}-\mathrm{ZrO}_{2}$ oxygen carrier particles for chemical-looping combustion," Chemical Engineering Science, vol. 62, pp. 6556-66567, 2007.

[52] A. Abad, J. Adánez, F. García-Labiano, L. F. de Diego, and P. Gayán, "Modeling of the chemical-looping combustion of methane using a Cu-based oxygen-carrier," Combustion and Flame, vol. 157, no. 3, pp. 602-615, 2010.

[53] Q. Song, R. Xiao, Z. Deng et al., "Chemical-looping combustion of methane with $\mathrm{CaSO}_{4}$ oxygen carrier in a fixed bed reactor," Energy Conversion and Management, vol. 49, no. 11, pp. 31783187, 2008.

[54] G. R. Kale, “Q science connect," pp. 1-12, 2012.

[55] G. R. Kale, B. D. Kulkarni, and K. V. Bharadwaj, "Chemical looping reforming of ethanol for syngas generation: a theoretical investigation," International Journal of Energy Research, vol. 37, no. 6, pp. 645-656, 2013.

[56] R. H. Perry and D. W. Green, Perry's Chemical Engineers' Handbook, McGraw-Hill, New York, NY, USA, 7th edition, 1997.

[57] J. P. E. Cleeton, C. D. Bohn, C. R. Müller, J. S. Dennis, and S. A. Scott, "Clean hydrogen production and electricity from coal via chemical looping: identifying a suitable operating regime," International Journal of Hydrogen Energy, vol. 34, no. 1, pp. 1-12, 2009.

[58] W. Xiang, S. Chen, Z. Xue, and X. Sun, "Investigation of coal gasification hydrogen and electricity co-production plant with three-reactors chemical looping process," International Journal of Hydrogen Energy, vol. 35, no. 16, pp. 8580-8591, 2010.

[59] M. Ortiz, A. Abad, L. F. de Diego, F. García-Labiano, P. Gayán, and J. Adánez, "Optimization of hydrogen production by Chemical-Looping auto-thermal Reforming working with Ni-based oxygen-carriers," International Journal of Hydrogen Energy, vol. 36, no. 16, pp. 9663-9672, 2011.

[60] HSC Chemistry [software]. Version 5.1 Pori: Outokumpu Research Oy, 2002.

[61] W. R. Smith, "Computer software reviews, HSC chemistry for windows, 2. 0.," Journal of Chemical Information and Computer Sciences, vol. 36, pp. 151-152, 1996.

[62] G. R. Kale, B. D. Kulkarni, and A. R. Joshi, “Thermodynamic study of combining chemical looping combustion and combined reforming of propane," Fuel, vol. 89, no. 10, pp. 3141-3146, 2010.

[63] G. R. Kale and B. D. Kulkarni, “Thermodynamic analysis of dry autothermal reforming of glycerol," Fuel Processing Technology, vol. 91, no. 5, pp. 520-530, 2010.
[64] G. R. Kale and B. D. Kulkarni, "An alternative process for gasoline fuel processors," International Journal of Hydrogen Energy, vol. 36, no. 3, pp. 2118-2127, 2011.

[65] E. Jerndal, T. Mattisson, and A. Lyngfelt, "Thermal analysis of chemical-looping combustion," Chemical Engineering Research and Design, vol. 84, no. 9, pp. 795-806, 2006.

[66] H.-B. Zhao, L.-M. Liu, D. Xu, C.-G. Zheng, G.-J. Liu, and L.L. Jiang, "NiO/ $\mathrm{NiAl}_{2} \mathrm{O}_{4}$ oxygen carriers prepared by sol-gel for chemical-looping combustion fueled by gas," Journal of Fuel Chemistry and Technology, vol. 36, no. 3, pp. 261-266, 2008.

[67] H. Leion, A. Lyngfelt, and T. Mattisson, "Solid fuels in chemicallooping combustion using a NiO-based oxygen carrier," Chemical Engineering Research and Design, vol. 87, no. 11, pp. 15431550, 2009.

[68] C. Dueso, A. Abad, F. García-Labiano et al., "Reactivity of a $\mathrm{NiO} / \mathrm{Al}_{2} \mathrm{O}_{3}$ oxygen carrier prepared by impregnation for chemical-looping combustion," Fuel, vol. 89, no. 11, pp. 33993409, 2010.

[69] C. Saha and S. Bhattacharya, "Comparison of $\mathrm{CuO}$ and $\mathrm{NiO}$ as oxygen carrier in chemical looping combustion of a Victorian brown coal," International Journal of Hydrogen Energy, vol. 36, no. 18, pp. 12048-12057, 2011.

[70] T. Mattisson, H. Leion, and A. Lyngfelt, "Chemical-looping with oxygen uncoupling using $\mathrm{CuO} / \mathrm{ZrO}_{2}$ with petroleum coke," Fuel, vol. 88, no. 4, pp. 683-690, 2009.

[71] K. Svoboda, A. Siewiorek, D. Baxter, J. Rogut, and M. Pohořelý, "Thermodynamic possibilities and constraints for pure hydrogen production by a nickel and cobalt-based chemical looping process at lower temperatures," Energy Conversion and Management, vol. 49, no. 2, pp. 221-231, 2008.

[72] H. Jin, T. Okamoto, and M. Ishida, "Development of a novel chemical-looping combustion: synthesis of a looping material with a double metal oxide of CoO-NiO," Energy and Fuels, vol. 12, no. 6, pp. 1272-1277, 1998.

[73] N. Ding, Y. Zheng, C. Luo, Q.-L. Wu, P.-F. Fu, and C.-G. Zheng, "Investigation into compound $\mathrm{CaSO}_{4}$ oxygen carrier for chemical-looping combustion," Journal of Fuel Chemistry and Technology, vol. 39, no. 3, pp. 167-168, 2011.

[74] M. Zheng, L. Shen, and J. Xiao, "Reduction of $\mathrm{CaSO}_{4}$ oxygen carrier with coal in chemical-looping combustion: effects of temperature and gasification intermediate," International Journal of Greenhouse Gas Control, vol. 4, no. 5, pp. 716-728, 2010.

[75] Z. Deng, R. Xiao, B. Jin, and Q. Song, "Numerical simulation of chemical looping combustion process with $\mathrm{CaSO}_{4}$ oxygen carrier," International Journal of Greenhouse Gas Control, vol. 3, no. 4, pp. 368-375, 2009.

[76] L. Shen, M. Zheng, J. Xiao, and R. Xiao, "A mechanistic investigation of a calcium-based oxygen carrier for chemical looping combustion," Combustion and Flame, vol. 154, no. 3, pp. 489-506, 2008.

[77] Z.-P. Gao, L.-H. Shen, J. Xiao, M. Zheng, and J.-H. Wu, "Analysis of reactivity of Fe-based oxygen carrier with coal during chemical-looping combustion," Journal of Fuel Chemistry and Technology, vol. 37, no. 5, pp. 513-520, 2009.

[78] B. Wang, H. Lv, H. Zhao, and C. Zheng, "Experimental and simulated investigation of chemical looping combustion of coal with $\mathrm{Fe}_{2} \mathrm{O}_{3}$ based oxygen carrier," Procedia Engineering, vol. 16, pp. 390-395, 2011.

[79] B.-W. Wang, R. Yan, Y. Zheng, H.-B. Zhao, and C.-G. Zheng, "Simulated investigation of chemical looping combustion with coal-derived syngas and $\mathrm{CaSO}_{4}$ oxygen carrier," Journal of Fuel Chemistry and Technology, vol. 39, no. 4, pp. 251-257, 2011. 
[80] R. Xiao and Q. Song, "Characterization and kinetics of reduction of $\mathrm{CaSO}_{4}$ with carbon monoxide for chemical-looping combustion," Combustion and Flame, vol. 158, no. 12, pp. 25242539, 2011.

[81] A. Shulman, E. Cleverstam, T. Mattisson, and A. Lyngfelt, "Chemical-looping with oxygen uncoupling using $\mathrm{Mn} / \mathrm{Mg}$ based oxygen carriers-oxygen release and reactivity with methane," Fuel, vol. 90, no. 3, pp. 941-950, 2011.

[82] L. F. de Diegoa, P. Gayán, J. Celaya, J. M. Palacios, and J. Adánez, "Operation of a $10 \mathrm{kWth}$ chemical-looping combustor during 200 h with a $\mathrm{CuO}-\mathrm{Al}_{2} \mathrm{O}_{3}$ oxygen carrier," Fuel, vol. 86, pp. 10361045, 2007.

[83] C. Saha, S. Zhang, K. Hein, R. Xiao, and S. Bhattacharya, "Chemical looping combustion (CLC) of two Victorian brown coals-part 1: assessment of interaction between $\mathrm{CuO}$ and minerals inherent in coals during single cycle experiment," Fuel, vol. 104, pp. 262-274, 2013. 


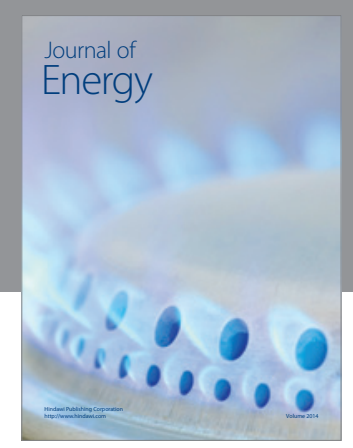

Journal of

Industrial Engineering
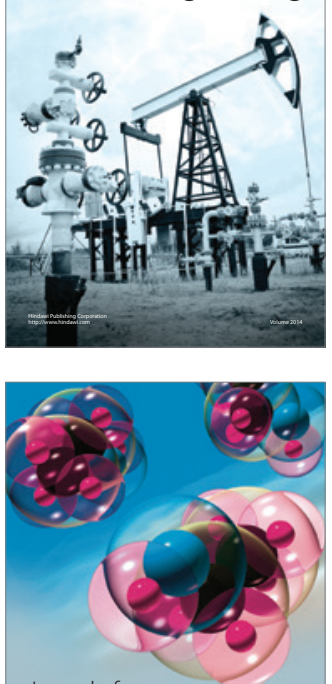

Fuels
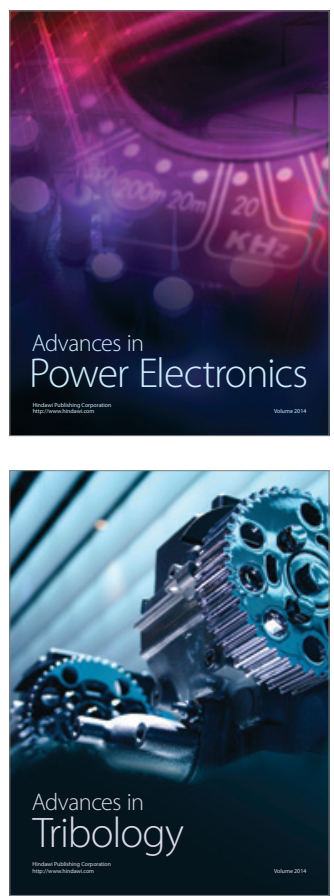

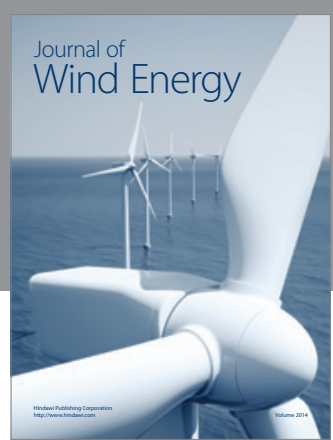

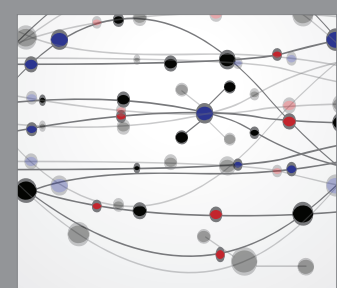

The Scientific World Journal

Submit your manuscripts at http://www.hindawi.com

Journal of

Structures
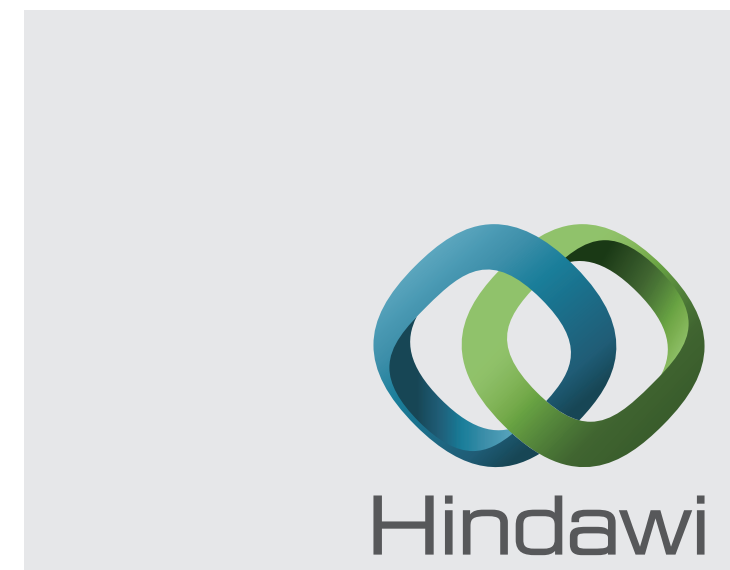

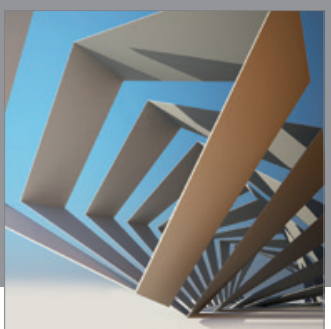

Rotating

Machinery
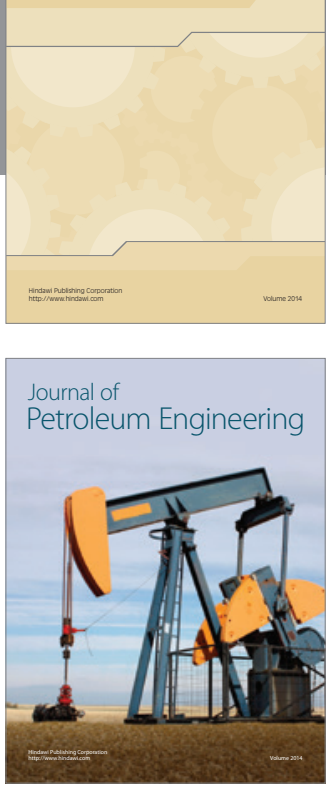

Journal of

Solar Energy
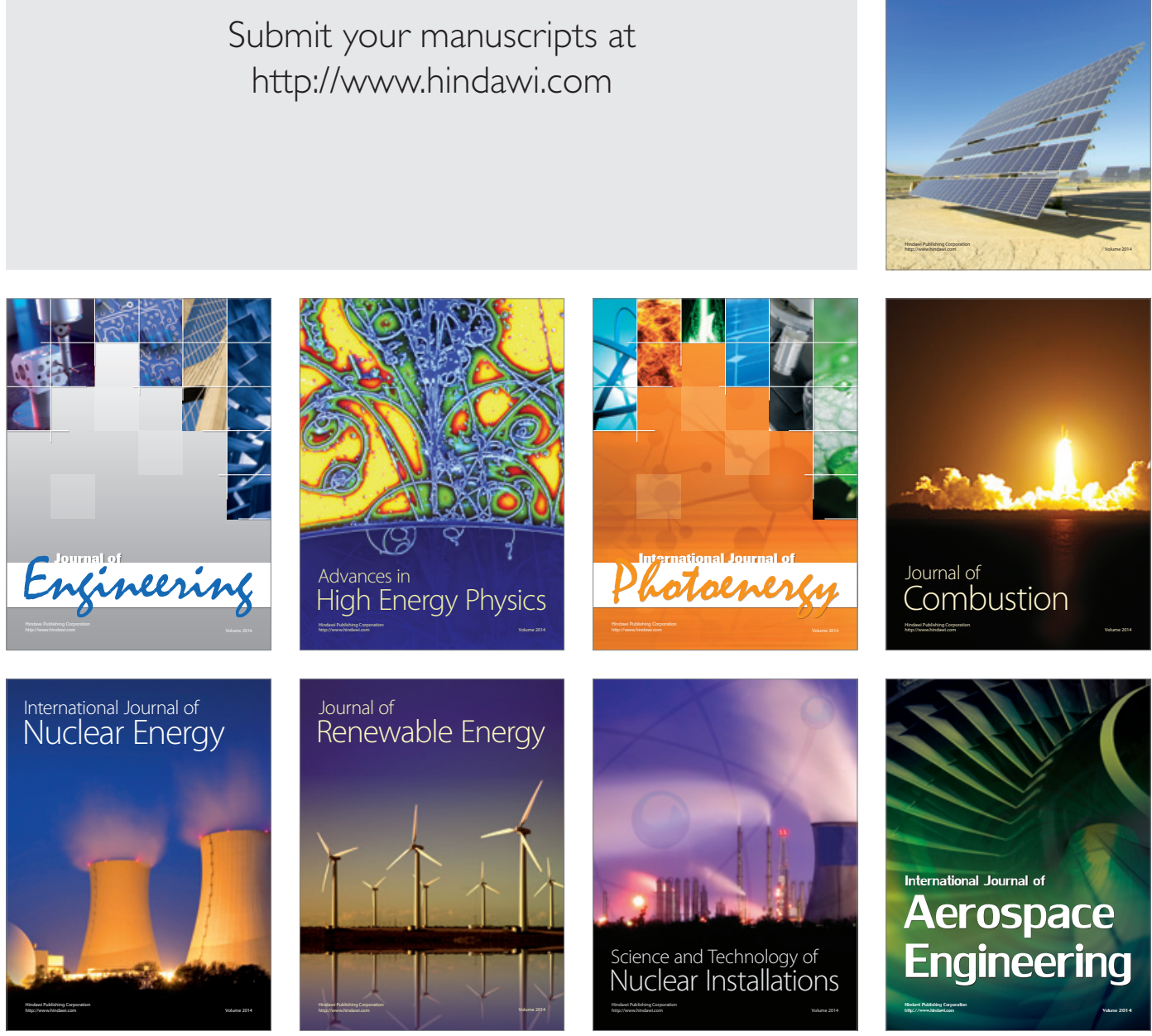